Article

\title{
Assessing Vegetation Decline Due to Pollution from Solid Waste Management by a Multitemporal Remote Sensing Approach
}

\author{
Giuseppe Mancino $^{1, * \mathbb{D}}$, Rodolfo Console ${ }^{1}$, Michele Greco ${ }^{2} \mathbb{D}$, Chiara Iacovino ${ }^{2} \mathbb{D}$, Maria Lucia Trivigno ${ }^{1}$ \\ and Antonio Falciano ${ }^{1}$ (D) \\ 1 Centro di Geomorfologia Integrata per l'Area del Mediterraneo, Via F. Baracca 175, 85100 Potenza, Italy; \\ r.console@cgiam.org (R.C.); 1.trivigno@cgiam.org (M.L.T.); a.falciano@cgiam.org (A.F.) \\ 2 Engineering School, University of Basilicata, 85100 Potenza, Italy; michele.greco@unibas.it (M.G.); \\ chiara.iacovino@unibas.it (C.I.) \\ * Correspondence: g.mancino@cgiam.org; Tel.: +39-0971-69511
}

check for updates

Citation: Mancino, G.; Console, R.; Greco, M.; Iacovino, C.; Trivigno, M.L.; Falciano, A. Assessing Vegetation Decline Due to Pollution from Solid Waste Management by a Multitemporal Remote Sensing Approach. Remote Sens. 2022, 14, 428. https://doi.org/10.3390/rs14020428 Academic Editors: Nicholas Coops and David M. Johnson

Received: 15 November 2021

Accepted: 13 January 2022

Published: 17 January 2022

Publisher's Note: MDPI stays neutral with regard to jurisdictional claims in published maps and institutional affiliations.

Copyright: (C) 2022 by the authors. Licensee MDPI, Basel, Switzerland. This article is an open access article distributed under the terms and conditions of the Creative Commons Attribution (CC BY) license (https:// creativecommons.org/licenses/by/ $4.0 /)$.

\begin{abstract}
Nowadays, the huge production of Municipal Solid Waste (MSW) is one of the most strongly felt environmental issues. Consequently, the European Union (EU) delivers laws and regulations for better waste management, identifying the essential requirements for waste disposal operations and the characteristics that make waste hazardous to human health and the environment. In Italy, environmental regulations define, among other things, the characteristics of sites to be classified as "potentially contaminated". From this perspective, the Basilicata region is currently one of the Italian regions with the highest number of potentially polluted sites in proportion to the number of inhabitants. This research aimed to identify the possible effects of potentially toxic element (PTE) pollution due to waste disposal activities in three "potentially contaminated" sites in southern Italy. The area was affected by a release of inorganic pollutants with values over the thresholds ruled by national/European legislation. Potential physiological efficiency variations of vegetation were analyzed through the multitemporal processing of satellite images. Landsat 5 Thematic Mapper (TM) and Landsat 8 Operational Land Imager (OLI) images were used to calculate the trend in the Normalized Difference Vegetation Index (NDVI) over the years. The multitemporal trends were analyzed using the median of the non-parametric Theil-Sen estimator. Finally, the Mann-Kendall test was applied to evaluate trend significance featuring areas according to the contamination effects on investigated vegetation. The applied procedure led to the exclusion of significant effects on vegetation due to PTEs. Thus, waste disposal activities during previous years do not seem to have significantly affected vegetation around targeted sites.
\end{abstract}

Keywords: multitemporal satellite; time series; remote sensing; Landsat; Theil-Sen estimator; MannKendall test; potential toxic elements; NDVI trend

\section{Introduction}

As early as the 1970s, a "new type of forest decline" [1] was observed almost simultaneously in various countries and in very different climatic and geo-pedological conditions and affecting different species of conifers and broad-leaved trees. The symptoms shown were not simply attributed to the classic biotic and abiotic stresses that cause a reduction in growth, a reduction in the leaf surface, the discoloration of the leaves, an arrest of or reduction in diameter increment, or a reduction in root phytomass and crown transparency. The phenomenon, whose causes have not yet been fully established, is still the subject of scientific research, but the contribution of Potential Toxic Elements (PTEs) in the decline of vegetation functionality is now well known and established. Among the PTEs, heavy metals (HMs) play a fundamental role, so much so that the European Environment Agency (EEA) has highlighted the importance [2] of the continuous monitoring of HM emissions 
in the environment at the European level. Such monitoring is a priority of international programs, such as the International Cooperative Program on Assessment and Monitoring of Air Pollution Effects on Forests (ICP Forests) and the International Cooperative Program on Integrated Monitoring of Air Pollution Effects on Ecosystems (ICP IM) of the United Nations Economic Commission for Europe (UNECE), and at national level in various parts of the world $[3,4]$.

Although HM pollution began with the industrial revolution [5], in recent decades there has been an increase in HM concentrations in the soil, which is causing serious environmental damage as a result of the problems of contamination. In fact, the quality of the environment and the activities of living organisms are influenced by contamination from HMs [6-8]. Where the excessive concentration of these metals concerns environments accessible to animals or plant species of food interest, animal and human health can also be compromised [9-11].

HMs can be released into the environment both for natural drivers and as a result of anthropogenic activities. The main causes of emissions are man-made sources, in particular, mining activities [12-14], industry and energy production [15,16], agriculture (fertilizers, pesticides, etc.), use of fossil fuels [17], waste disposal [18-20] and population growth and concentration in large urban areas [21,22]. The demographic and industrial increase has led to a huge production of waste that is treated, stored, collected and disposed of, involving risks for the environment in various phases [23,24]. The controlled or uncontrolled disposal of waste can accidentally cause the leakage and migration of contaminants, including inorganic ones, such as HMs, with a significant impact on the environment [25]. In some cases, the metals emitted continue to persist in the environment for many years, even after the decommissioning of anthropogenic activities.

Together with essential elements, HMs are absorbed by plants from the soil, giving rise to potentially risky bioaccumulation phenomena not only for flora and fauna but also for human health. The toxicity of HMs in plants depends on the plant species, the chemical element, its concentration and the soil's chemical-physical characteristics. The elements that can be significantly accumulated in plants are $\mathrm{Cr}, \mathrm{Mn}, \mathrm{Fe}, \mathrm{Ni}, \mathrm{Cu}, \mathrm{Zn}, \mathrm{Cd}, \mathrm{Pb}$ and $\mathrm{Hg}$. The problems caused by HMs are well known for plants [26-30]: growth reduction [31-34] until reaching high levels of toxicity capable of causing death [35]. In fact, high concentrations of HMs damage plant structures, such as through the replacement of essential ions with free radicals that affect the protein and enzymatic structure [36]. Furthermore, high concentrations of HMs in the soil negatively interfere with the radical absorption of essential nutrients, affecting physiological processes such as respiration and photosynthesis. HMs also favor the production of Reactive Oxygen Species (ROS) by self-oxidation [37], which, in turn, results in negative effects on lipids and proteins of the cell membrane, on permeability, on Deoxyribo-Nucleic Acid (DNA) and on photosynthetic properties, ultimately causing physiological stress, alterations in phenology and growth reduction [38-40]. Further negative effects are attributable to physiological processes such as germination, accumulation and remobilization of reserve substances during germination [41].

The functional alterations of plants due to HM pollution result in morphological modifications concerning the pigment content [42], the mesophyll structure, the leaf surface characteristics $[43,44]$ and the canopy architecture [45]. With regard to physiology, variations concern the transpiration rate and photosynthesis [46,47], the stomatal conductance $[48,49]$ and, consequently, the leaf temperature [50,51]. Other known effects range from the reduction in the number of leaves to the reduction in leaf surface and green pigments, and therefore to chlorosis [52], necrosis, leaf epynasty and red-brown discoloration $[3,4,53]$. Among the latter, chlorosis is probably the most common phenomenon in response to HM pollution stresses [33], causing a reduction in chlorophyll absorption around the spectral ranges of $680 \mathrm{~nm}$ and $550 \mathrm{~nm}$ [54].

Such a plant response affects the spectral reflectance of foliage and canopy under an increasing geochemical stress [55,56]. Moreover, reflectance changes can be speciesdependent [57] and influenced by environmental variables that affect the HM concentra- 
tions in plants [58]. Many studies have highlighted the ability of satellite remote sensing (RS) to identify geochemical stresses on plants induced by high HM concentrations through changes in the spectral responses in various ranges, in particular, visible and infrared (IR) [59-61]. In more detail, an increase in spectral reflectance in the red region and a significant reduction in the near infrared (NIR) was observed [62,63]. Thus, the use of Vegetation Indices (VI), based on the spectral transformation of two or more bands, tends to minimize the disturbances due to the reflectance contribution of soil, atmosphere and other external factors [64,65], highlighting the spectral aliquot of vegetation [66-68].

The NDVI Vegetation Index, based on the normalized difference of the red and NIR bands, which are more sensitive to the variations induced by contamination, is particularly suitable for the multitemporal identification of the physiological efficiency of vegetation [69] and for the space-time comparison of photosynthetic activity [51,70]. In fact, NDVI is widely used for the evaluation of plant biomass, the leaf area index (LAI), photosynthetic activity and chlorophyll content; namely, all factors more or less strongly influenced by the presence of HMs.

Traditional methods for monitoring HM contamination involve soil and plant tissue analysis, providing very accurate data yet very onerous and expensive to sample; therefore, they are not applicable on a large scale [71,72]. On the other side, RS represents a valid alternative method for monitoring HM contamination [73-75]. It has been shown that HM contamination causes a reduction in the dry mass of plants even before alterations of the photosynthetic mechanisms occur [47]. Thus, RS techniques are potentially able to identify any contamination before clear evidence on vegetation [54]. Some RS studies are based on the implementation of models correlating the satellite spectral response with the variation of physiological and morphological parameters of vegetation as a result of different levels of contamination [76-78]. The main advantages of RS are to provide information in near real-time with high efficiency in identifying vegetation state changes and to be a non-destructive, low-cost methodology that provides large-scale data [79]. The negative consequences of high concentrations of HMs accumulated in plants can clearly manifest their effects over time [80]. Therefore, long-term observations of vegetation are of considerable importance [81]. In this perspective, a multitemporal analysis of RS data can be used to identify HM contamination in a wide area, further because the stresses induced by HM contamination have the characteristic of being stable in space and time [50]. In addition, the continuous, multitemporal and large-scale monitoring by RS allows policymakers to implement decision support systems for land management aimed at restoring ecosystem functionality and resilience capacity [4]. It should be noted that the effects induced by HM pollution could be confused with other factors (water stress, nutrient deficiency, diseases and infestations, climatic anomalies, mismanagement, etc.) affecting vegetation functionality and causing the same macroscopic effects $[51,82,83]$ and, therefore, very similar spectral variations. However, the latter stressors have a limited effect over time, while the toxicity due to HM bioaccumulation persists over years [50]. Starting from these assumptions, this work led to:

(a) Multitemporal analysis of vegetation change in areas surrounding potentially polluted sites, through the study of NDVI trends.

(b) Identification of a statistical procedure for analyzing the physiological trends of vegetation that did not take into account variations due to external factors with respect to PTE pollution.

(c) Analysis of the statistical significance of the multitemporal trends of NDVI for the possible identification of areas of environmental criticality due to the effect of contamination.

\section{Materials and Methods}

\subsection{Study Sites}

The pilot sites for the multitemporal monitoring of vegetation consisted of territorial areas affected by pollution issues, both in terms of overt contamination of environmental matrices as well as potential threats to the environment and public health. 
In particular, the following three sites (Figure 1) located in the north-western part of the Basilicata region (Italy) were analyzed:

- $\quad$ The landfill of Aia dei Monaci, located in the municipality of Tito;

- The landfill complex in the Montegrosso-Pallareta area of Potenza;

- The former incinerator, later a waste transfer center, in Vallone Calabrese, Potenza.

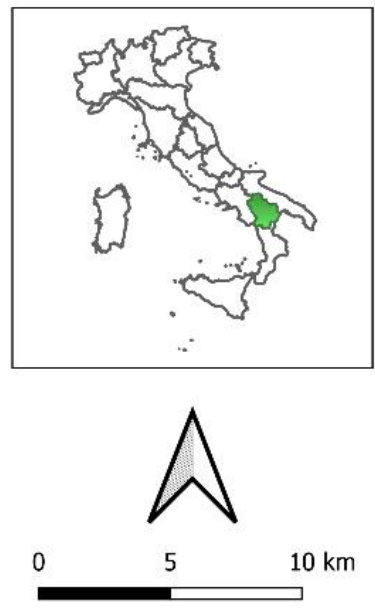

Coordinate Reference System: WGS84

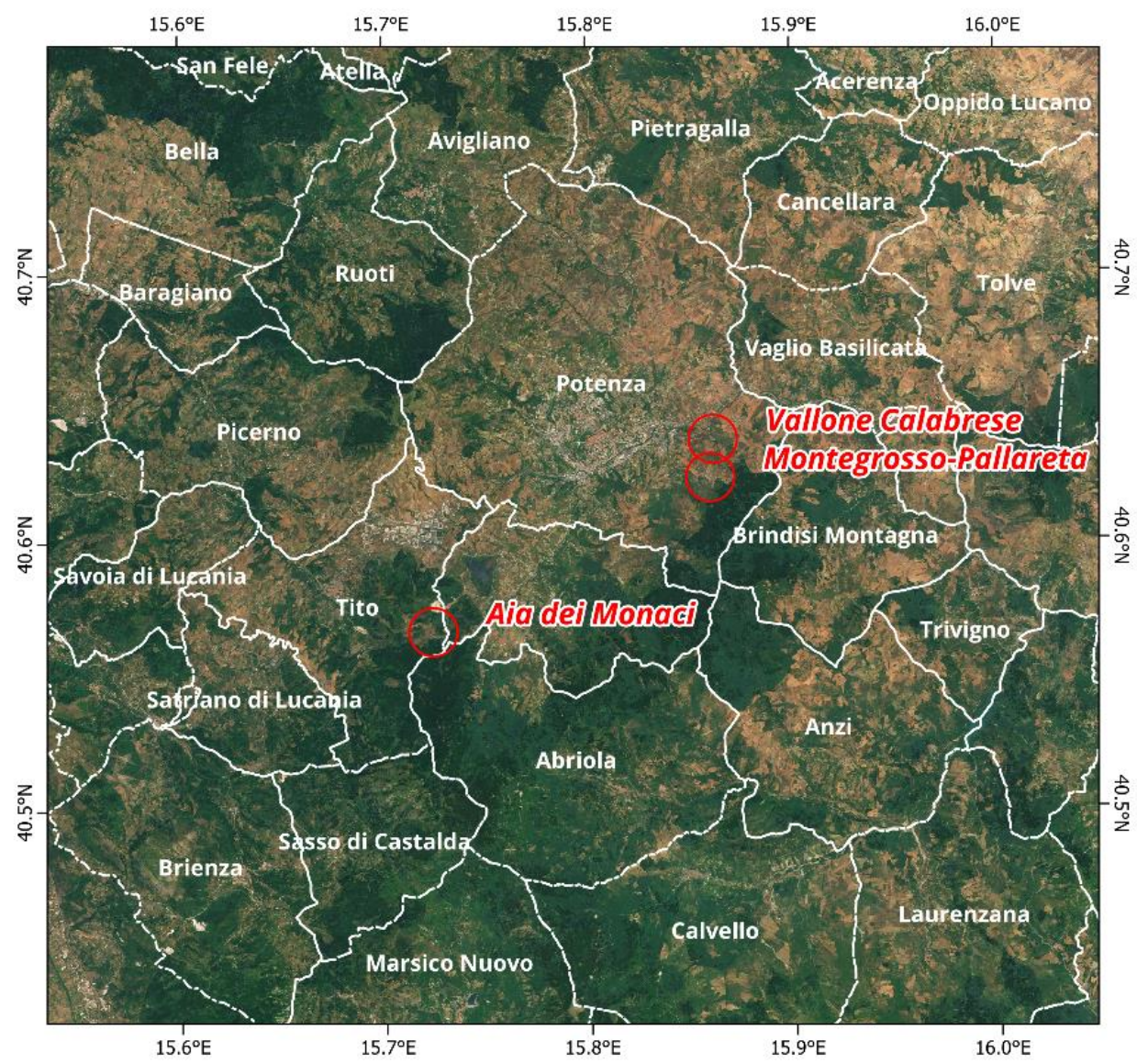

Figure 1. Overview of the study areas on "Sentinel-2 cloudless-https://s2maps.eu (accessed on 14 November 2021) by EOX IT Services GmbH (Contains modified Copernicus Sentinel data 2017 \& 2018)".

The complex located in Aia dei Monaci was first used as a landfill for municipal solid waste (MSW) from 1994 to 2004, when the authorized volumes were exhausted, and then as a waste transfer station for MSW, serving the municipalities of the Bacino "Potenza Centro" from 2007 to 2014. At present, the transfer station is inactive, and no waste treatment or storage activities are carried out on the site. Its Site Characterization Plan is being implemented.

In the site of Montegrosso-Pallareta (Potenza), there is a complex of landfills whose work began in 1986 and that was responsible for waste disposal in May 1989. Since February 2009, it has housed an MSW transfer station inside of it, serving 18 municipalities in the hinterland of Potenza. Nowadays, the activities of the waste transfer station are suspended. The various basins are not in operation; therefore, they have been closed according to the procedures established by the regulations in force at the time of filling the basins.

The former incinerator in Vallone Calabrese (Potenza), built between 1988 and 2003, only came into partial operation at the end of 2005 with the start of the testing procedures, the "hot tests" of the industrial plants, pending the completion of the authorization process for the exercise. The activity, up to that moment being provisional and never fully operational, ended in 2007. Today, the structures that house the industrial plants 
are not operational and there is no waste management and/or handling. The area is used as a depot for snow vehicles and other equipment for the ordinary operation of the "Azienda Comunale per la Tutela Ambientale" (ACTA), the local Municipal Environmental Protection Agency.

The above-mentioned study areas are reported as "potentially polluted sites" in the "Registry of the sites subject to the remediation procedure" of the Basilicata region as analyses carried out over the years on various environmental matrices (groundwater, surface water, soil) have shown the following analytes to be out of range:

- $\quad$ At Aia dei Monaci, $299 \mu \mathrm{g} / \mathrm{L}$ of iron, $2697 \mu \mathrm{g} / \mathrm{L}$ of manganese and $22 \mu \mathrm{g} / \mathrm{L}$ of nickel (threshold values are 200, 50 and $20 \mu \mathrm{g} / \mathrm{L}$, respectively).

- At Montegrosso-Pallareta, off-threshold values sampled in groundwater relate to nickel $(88 \mu \mathrm{g} / \mathrm{L})$, lead $(193 \mu \mathrm{g} / \mathrm{L})$, sulphates $(6400 \mu \mathrm{g} / \mathrm{L})$ and manganese $(2000 \mu \mathrm{g} / \mathrm{L})$, where thresholds are 20,10, 250 and $50 \mu \mathrm{g} / \mathrm{L}$, respectively.

- At Vallone Calabrese, threshold values have been exceeded both for groundwater (sulphates, aluminum, manganese and lead) and soil matrices, where the measured copper concentration was $1500 \mathrm{mg} / \mathrm{kg}$ dry matter (DM) against a threshold of $600 \mathrm{mg} / \mathrm{kg}$ DM.

The excerpts of the orthophoto AGEA 2017 and the land use map of the Basilicata region for each study area are depicted in Figure 2. The land use classes falling within the sites of interest are shown in Table 1.

a)
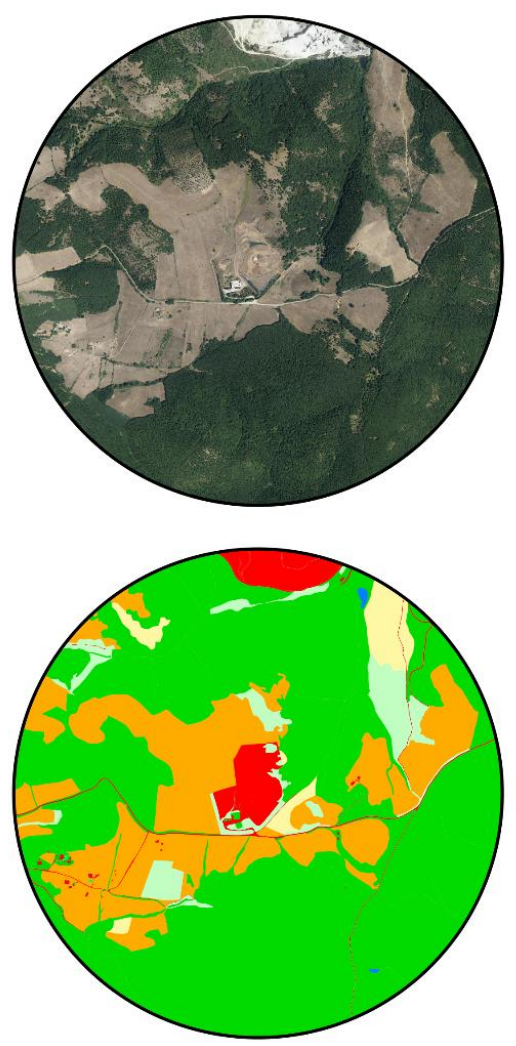

1 b)
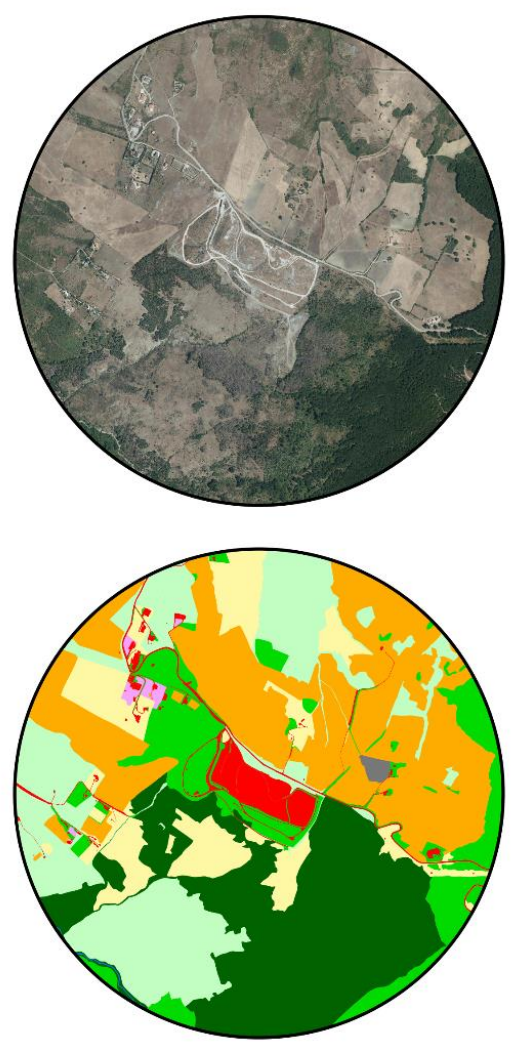

0
1 c)
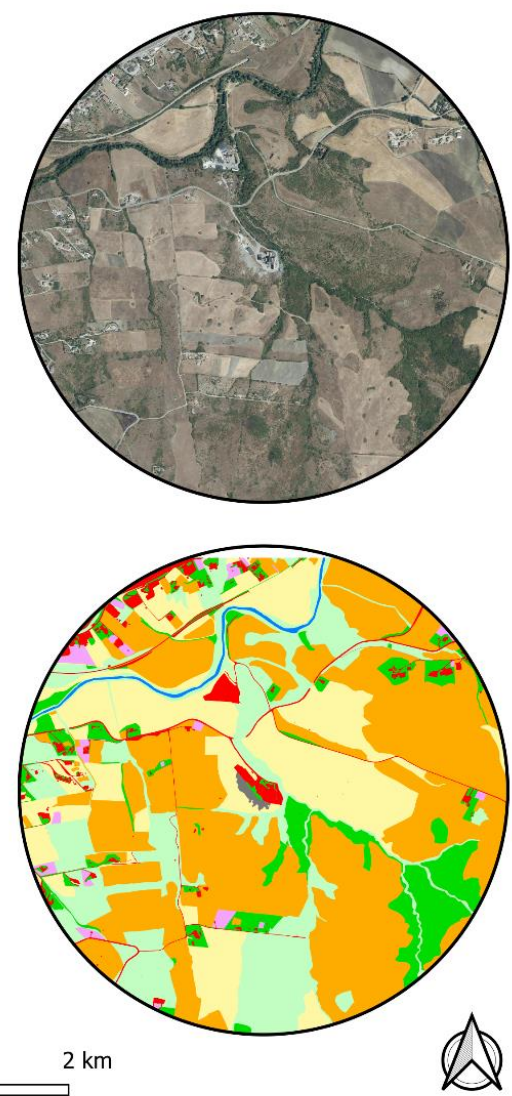

321 - Natural grasslands

324 - Transitional woodland-shrub

332 - Bare rocks

51 - Inland waters
Land use

1 - Artificial surfaces

- 122 Road and rail networks

211 - Non-irrigated arable land

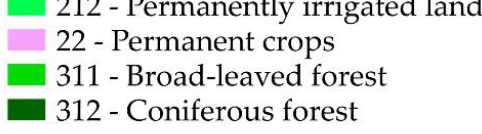

Figure 2. Orthophoto and land use map of study areas: (a) Aia dei Monaci, (b) Montegrosso-Pallareta, (c) Vallone Calabrese. 
Table 1. Land use class distribution in the three study sites.

\begin{tabular}{|c|c|c|c|c|c|c|c|}
\hline \multirow{2}{*}{ Code } & \multirow{2}{*}{ Description } & \multicolumn{2}{|c|}{ Aia dei Monaci } & \multicolumn{2}{|c|}{ Montegrosso-Pallareta } & \multicolumn{2}{|c|}{ Vallone Calabrese } \\
\hline & & Count & $\%$ & Count & $\%$ & Count & $\%$ \\
\hline 1 & Artificial surfaces & 136 & 3.9 & 88 & 2.5 & 64 & 1.8 \\
\hline 122 & Road and rail networks & 40 & 1.1 & 55 & 1.6 & 97 & 2.8 \\
\hline 211 & Non-irrigated arable land & 818 & 23.5 & 1006 & 28.8 & 1505 & 43.1 \\
\hline 212 & Permanently irrigated land & 1 & 0.0 & 0 & 0.0 & 0 & 0.0 \\
\hline 22 & Permanent crops & 0 & 0.0 & 17 & 0.5 & 49 & 1.4 \\
\hline 311 & Broad-leaved forest & 2224 & 63.8 & 378 & 10.8 & 318 & 9.1 \\
\hline 312 & Coniferous forest & 0 & 0.0 & 818 & 23.5 & 0 & 0.0 \\
\hline 321 & Natural grasslands & 97 & 2.8 & 376 & 10.8 & 739 & 21.2 \\
\hline 324 & Transitional woodland-shrub & 168 & 4.8 & 740 & 21.2 & 676 & 19.4 \\
\hline 332 & Bare rocks & 0 & 0.0 & 9 & 0.3 & 21 & 0.6 \\
\hline \multirow[t]{2}{*}{51} & Inland waters & 4 & 0.1 & 1 & 0.0 & 19 & 0.5 \\
\hline & Total & 3488 & 100.0 & 3488 & 100.0 & 3488 & 100.0 \\
\hline
\end{tabular}

\subsection{Satellite Data}

The constellation of existing satellites and the characteristics of onboard sensors were analyzed to reconstruct the vegetation trends. The choice fell on the Landsat constellation as it is the longest earth observation (EO) program, providing data for the past 50 years, and the satellites of its missions have almost comparable sensors onboard, if applying appropriate intercalibration procedures. The good geometric resolution of Landsat images is able to identify with sufficient accuracy the changes occurring on the Earth's surface. Landsat 7 Enhanced Thematic Mapper Plus (ETM+) images were discarded from the analyses due to Scan Line Corrector (SLC)-Off causing data gaps since June 2003 that affect two of the three study areas almost entirely. Therefore, only Landsat $5 \mathrm{TM}$ and Landsat 8 OLI images were considered (Table 2), acquired in the time span between 1990 and 2018 and referred to the summer months (generally July and August) when the percentage of cloud cover is near to zero on survey sites.

Table 2. Landsat $5 \mathrm{TM}$ and Landsat $8 \mathrm{OLI}$ images used in the time series analysis (Worldwide Reference System-WRS-Path/Row 188/32).

\begin{tabular}{cc}
\hline Satellite Sensor & Date of Acquisition \\
\hline Landsat 5 TM & 23 July 1990 \\
Landsat 5 TM & 31 July 1993 \\
Landsat 5 TM & 5 July 1993 \\
Landsat 5 TM & 17 August 1999 \\
Landsat 5 TM & 22 June 2002 \\
Landsat 5 TM & 19 July 2006 \\
Landsat 5 TM & 22 June 2008 \\
Landsat 5 TM & 18 August 2011 \\
Landsat 8 OLI & 7 August 2013 \\
Landsat 8 OLI & 10 August 2014 \\
Landsat 8 OLI & 13 August 2015 \\
Landsat 8 OLI & 15 August 2016 \\
Landsat 8 OLI & 2 August 2017 \\
Landsat 8 OLI & 4 July 2018 \\
\hline
\end{tabular}

The atmospheric correction of the images, absolutely necessary when dealing with satellite image time series, was carried out using the 6SV algorithm [84-86]. This algorithm, extensively tested to ensure its accuracy [87], has undergone several evolutions and in the current version includes the effects of polarization, which has a substantial role on method accuracy [88]. 6SV currently represents one of the most efficient algorithms for various multispectral sensors $[89,90]$. The subsequent cloud masking operation was necessary 
in order to detect the presence of cloud cover and related shadows in order to identify the images to be excluded from the analysis in the study areas. The algorithm used was Fmask [91,92], which is particularly suitable for the correct identification of clouds and shadows in Landsat images [93,94]. Finally, the time series images were cropped on the whole study area, including all three sites of interest.

\subsection{Analysis of the Vegetation Evolution}

Starting from the Landsat data, a methodology for analyzing NDVI temporal trends was developed to obtain respective maps of the vegetation evolution/involution and maps of the environmental criticalities, both over the 1990-2018 timeframe (Figure 3).

a)

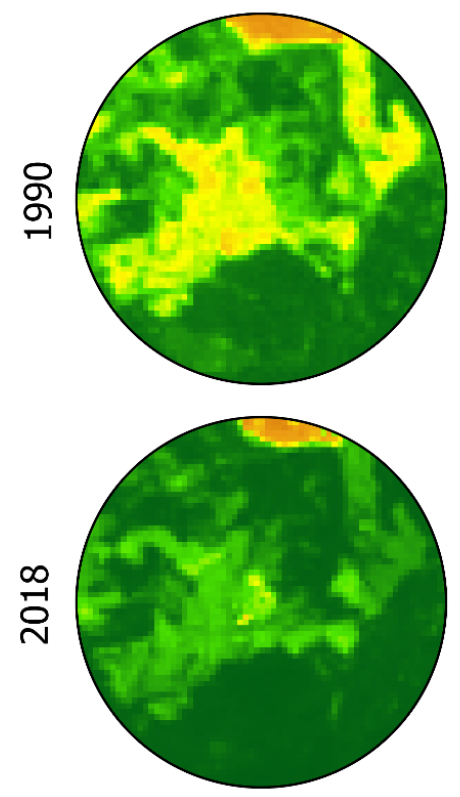

b)

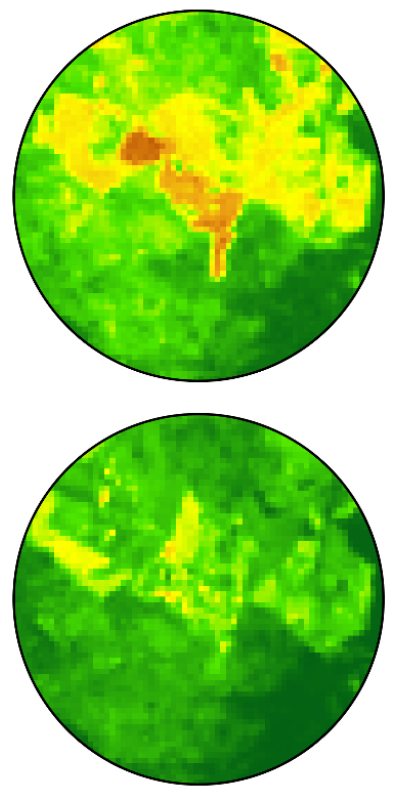

C)

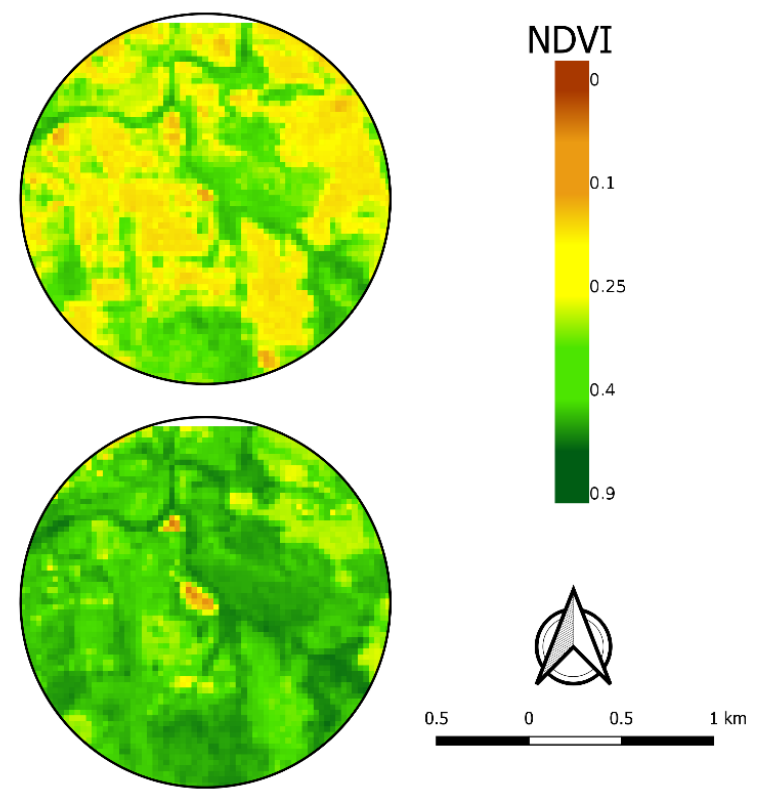

Figure 3. Initial and final NDVI maps of the three study areas: (a) Aia dei Monaci, (b) MontegrossoPallareta, (c) Vallone Calabrese.

The procedure adopted for the multitemporal analysis of processed Landsat data in the period 1990-2018 was the Theil-Sen median trend [95,96]. The non-parametric Theil-Sen estimator tends to produce accurate confidence intervals even when data are not normally distributed $[97,98]$ and in the presence of heteroskedasticity $[99,100]$. The method is robust with regard to outliers [101,102], which are always present in a time series of RS data and represent a "disturbance" with respect to the analysis of vegetation trends. Furthermore, in RS, this non-parametric procedure is considered robust with respect to the seasonality, non-normality and frequently present autocorrelation both at intra and interannual scale [103-105].

The procedure allows computing the slope of the line joining the medians of the trends calculated for each pair of points belonging to the dataset. Such a slope is calculated as follows [95,96]:

$$
\beta=\operatorname{median}\left(\frac{x_{i}-x_{j}}{i-j}\right), \forall j<i
$$

where $\beta$ is the slope between the data of two points in the time series, and $x_{i}$ and $x_{j}$ are the corresponding values between the two points $i$ and $j$ (for $j<i$ ). The procedure is applied independently to each pixel and calculates the median of the slopes between all the $n(n-1) / 2$ pair combinations of pixels over time. The final result provides the rate of change for the considered time step, e.g., year, month, week, etc. [106]. 
The Theil-Sen method tends to provide similar results to the Ordinary Least Squares (OLS) regression [107-109] for identifying the line slope when there are many observations (e.g., very long historical series and/or annual data on a daily, weekly basis, etc.) that exclude the effect of outliers [110-112]. For small observations, the median trend provides more robust results and is particularly suitable for the treatment of RS data, especially at medium and high spatial resolution and, therefore, with reduced observation frequency $[113,114]$.

The main advantage of Theil-Sen is its "breakdown bound"; for a robust estimator, the number of outliers that can be present in the dataset before the trend is affected by them is approximately $29 \%$ [106]. In such a case, the important implication is that the observations affected by strong inter-annual climatic oscillations or significant variations due to external factors are not taken into consideration compared to those to be observed.

\subsection{Analysis of Environmental Criticalities}

Once vegetation trends were identified, their significance was analyzed, identifying the areas that had undergone environmental stress over the years such as to induce a significant reduction in physiological efficiency.

To carry out this verification, the Mann-Kendall test was used, starting from the TheilSen slope trends. In fact, the Z Mann-Kendall test [115-117] is not only able to verify the existence of a trend but also to estimate its statistical significance (separating the hypothesis $\mathrm{HO}=$ absence of trend from $H 1=$ presence of monotonous trend). On the other hand, $\mathrm{Z}$ Mann-Kendall is not able to identify the trend monotonicity, unlike the Theil-Sen slope estimator. Instead, because the Theil-Sen estimator does not provide any information regarding trend significance, it is very often used in combination with the Mann-Kendall test $[79,118-121]$.

The Mann-Kendall $Z$ test estimates the trend significance by measuring the magnitude of the relationship between two successive points. Assuming a time series $t_{1}, t_{2}, \ldots, t_{n}$, corresponding to a data series $x_{1}, x_{2}, \ldots, x_{n}$, the value $S$ of the Mann-Kendall test $[115,116]$ is:

$$
\begin{gathered}
S=\sum_{i=1}^{n-1} \sum_{j=i+1}^{n} \operatorname{sign}\left(x_{i}-x_{j}\right) \\
\operatorname{sign}\left(x_{i}-x_{j}\right)=\left\{\begin{array}{cc}
1 & \text { if } x_{i}-x_{j}<0 \\
0 & \text { if } x_{i}-x_{j}=0 \\
-1 & \text { if } x_{i}-x_{j}>0
\end{array}\right.
\end{gathered}
$$

where $n$ is the length of the time series, and $x_{i}$ and $x_{j}$ are the observations, respectively, at time $i$ and $j$. When $n \geq 10$, the Mann-Kendall test's statistical value $S$ is similar to a normal distribution with a mean equal to 0 . The variance of $S$ is:

$$
\operatorname{Var}(S)=\frac{n(n-1)(2 n+5)}{18}=\sigma^{2}
$$

The Mann-Kendall $Z$ value is used to identify where the trend is significant:

$$
Z= \begin{cases}\frac{S-1}{\sqrt{\operatorname{Var}(S)}} & \text { if } S>0 \\ 0 & \text { if } S=0 \\ \frac{S+1}{\sqrt{\operatorname{Var}(S)}} & \text { if } S<0\end{cases}
$$

$|Z|>Z(\alpha / 2)$, where $\alpha$ is the level of significance, means that the time series shows a significant trend, increasing for $S>0$ and decreasing for $S<0$. The significance level considered for remotely sensed data is usually $0.05[106,122,123]$. For $\alpha=0.05, Z(\alpha / 2)=1.96$. This means that for $|Z|>1.96$, there is a significant trend of increase or decrease. The level of significance is particularly suitable for the analysis of a time series of RS data in order to verify the significance of NDVI trends [106,124,125]. 


\section{Results}

The analyses for the identification of the multitemporal trends of the vegetation were conducted on a circular area with a radius of $1 \mathrm{~km}$ starting from each site's centroid. The consideration underlying this assumption was that any possible variation in the vegetation functional efficiency induced by the anthropogenic stresses was evident in an area not far from potentially polluting sources [126-129]. For a unit area of $900 \mathrm{~m}^{2}$ (pixel size), the obtained maps identify the multitemporal variation of the vegetation efficiency at different levels of intensity and, thus, the environmental criticalities.

\subsection{Maps of the Vegetation Evolution}

The Theil-Sen slope map (Figure 4) was calculated for the NDVI, a vegetation index that is able to express any eco-physiological stresses on vegetation [42,130]. Therefore, starting from the NDVI Theil-Sen slope, a map of the vegetation evolution (Figure 5) was created for each study area to identify any stresses and trace them to the factors that they induced. In more detail, this map on vegetation growth/degrowth rates in the period 1990-2018 identifies the following classes:

- Three classes of vegetation involution (slight, moderate and strong decrease);

- An intermediate class containing the invariant areas, defined as "constant";

- $\quad$ Three classes of vegetation evolution (slight, moderate and strong increase).
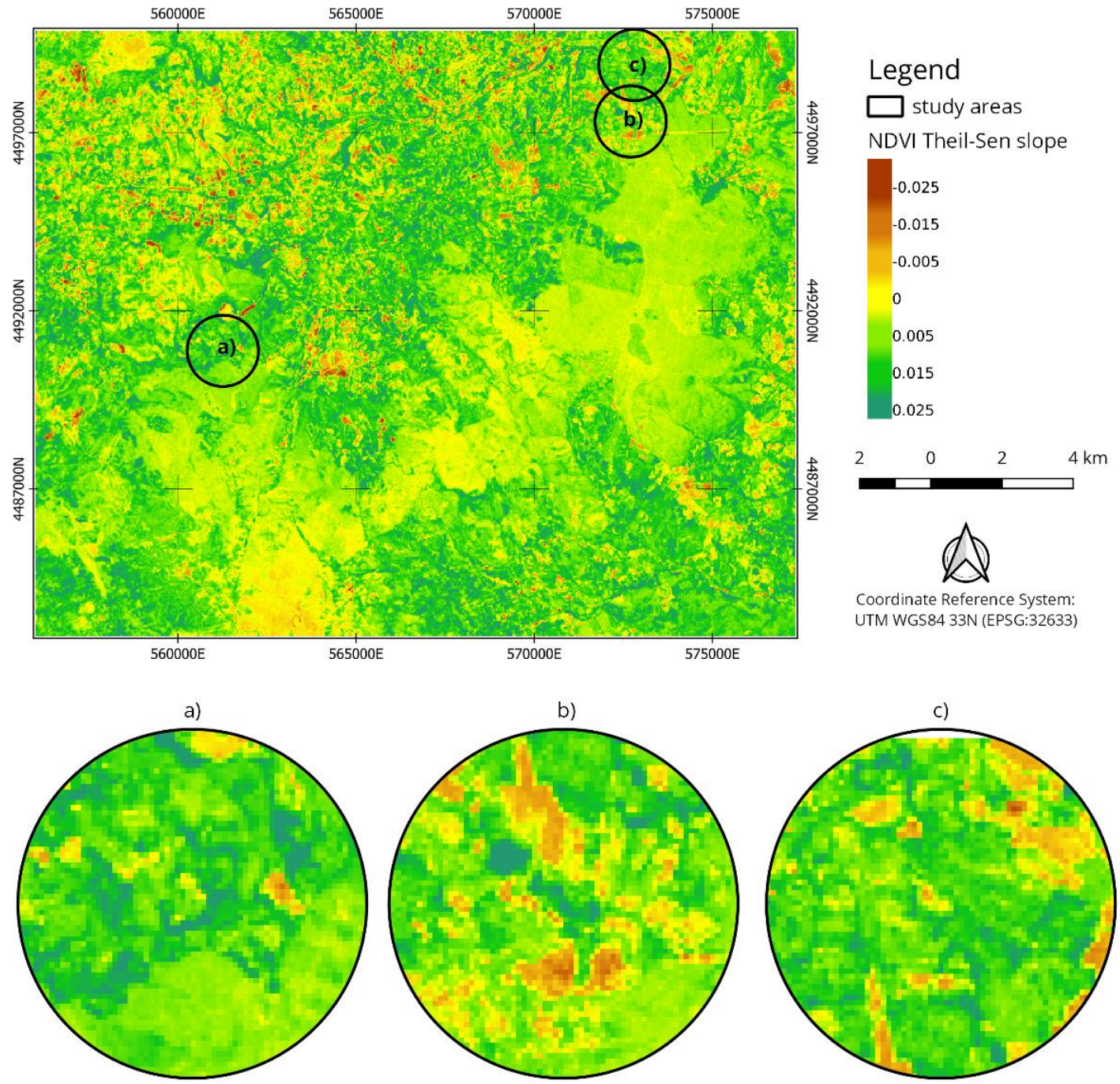

Figure 4. NDVI Theil-Sen slope map of the whole study area and related detail maps of the three sites of interest: (a) Aia dei Monaci, (b) Montegrosso-Pallareta, (c) Vallone Calabrese. 


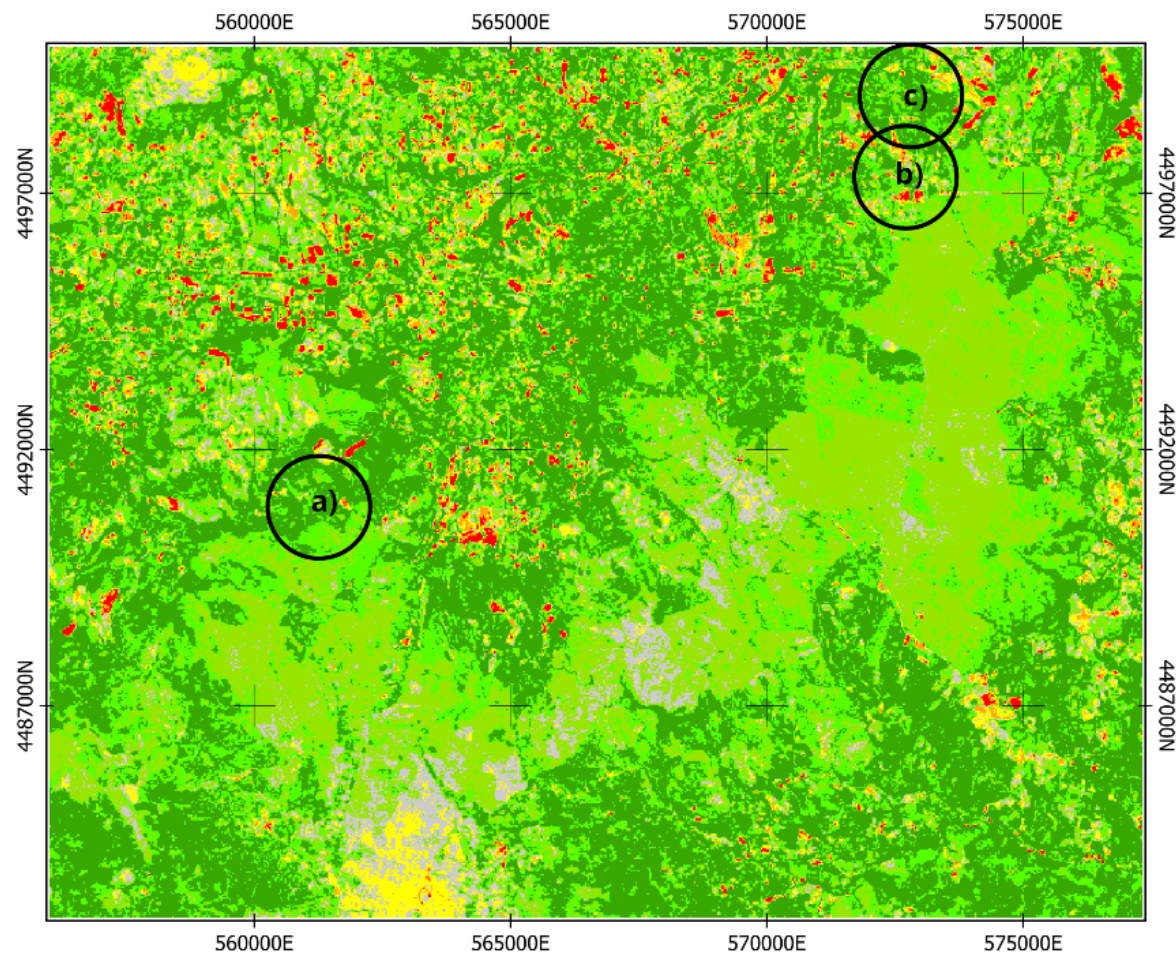

\section{Legend}

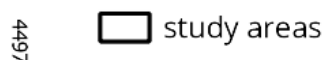

Vegetation evolution

strong decrease

moderate decrease

slight decrease

constant

slight increase

moderate increase

strong increase

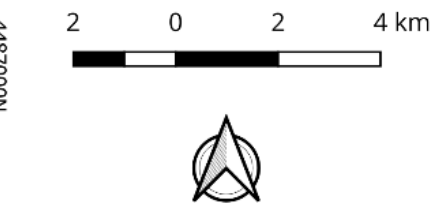

Coordinate Reference System: UTM WGS84 33N (EPSG:32633)

a)
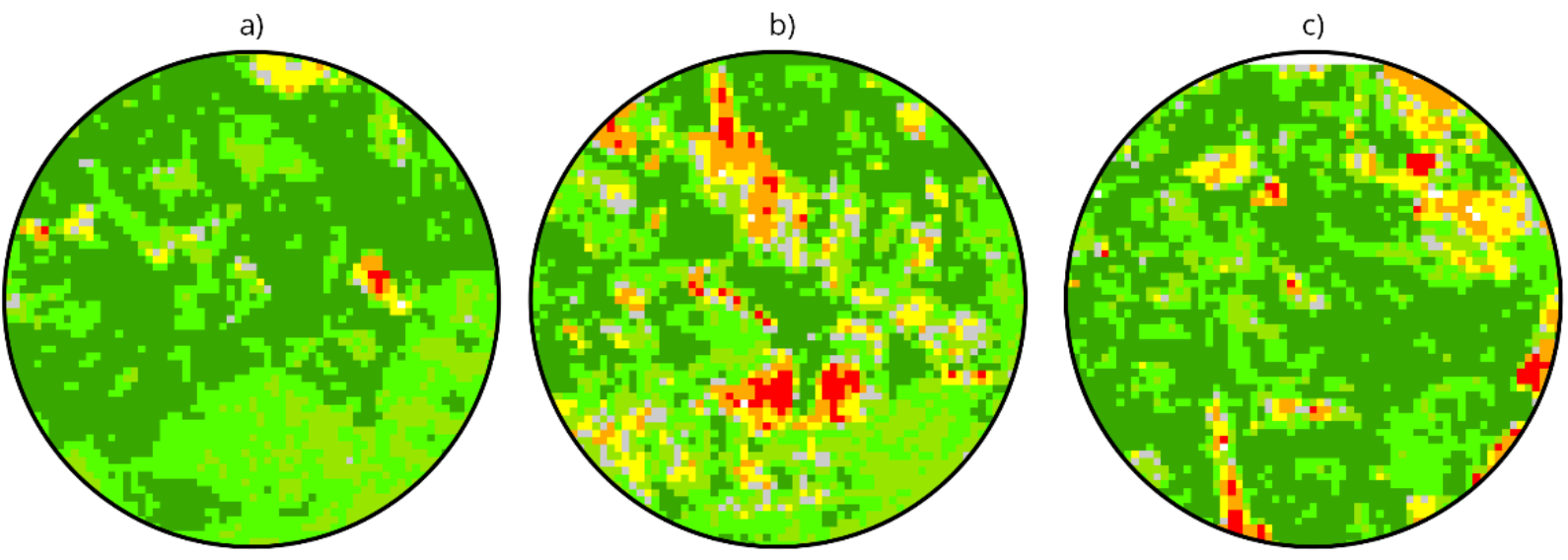

Figure 5. Map of the vegetation evolution of the whole study area and related detail maps of the three sites of interest: (a) Aia dei Monaci, (b) Montegrosso-Pallareta, (c) Vallone Calabrese.

For the survey sites, consisting of circular areas with a radius of $1 \mathrm{~km}$, the distribution percentages of the vegetation evolution classes are shown in Table 3.

For Aia dei Monaci, the areas showing a decrease in vegetation were very small (about $2.5 \%$ ), with consistent decreases affecting only six pixels ( $0.2 \%)$. Even the invariant areas were very limited in extent, while those that showed increases exceeded $96 \%$ in the timeframe considered, with very sustained increases reaching approximately $54 \%$.

For the Montegrosso-Pallareta site, the total areas of decrease were approximately 15\% and, therefore, they were certainly more consistent than in Aia dei Monaci, although the areas with a significant decrease were around 2\%. Unlike how the Aia dei Monaci site falls within a distinct agro-forestry area characterized by clearly reduced land use changes, the Montegrosso-Pallareta site falls in a peri-urban area with a high complexity of landscape dynamics. In fact, since the 1990s, urbanization processes and land use changes have been faster and have involved larger surfaces. Thus, the agro-forestry land use dynamics were more sudden with an alternation of crop abandonment, cultivation of uncultivated areas, afforestation, etc. 
Table 3. Percentage distribution of the vegetation evolution classes in the survey sites.

\begin{tabular}{|c|c|c|c|c|c|c|}
\hline \multirow{2}{*}{$\begin{array}{c}\text { Vegetation } \\
\text { Evolution Classes }\end{array}$} & \multicolumn{2}{|c|}{ Aia dei Monaci } & \multicolumn{2}{|c|}{ Montegrosso-Pallareta } & \multicolumn{2}{|c|}{ Vallone Calabrese } \\
\hline & Count & $\%$ & Count & $\%$ & Count & $\%$ \\
\hline Strong decrease & 6 & 0.2 & 74 & 2.1 & 45 & 1.3 \\
\hline Moderate decrease & 17 & 0.5 & 192 & 5.5 & 133 & 3.9 \\
\hline Slight decrease & 63 & 1.8 & 249 & 7.1 & 201 & 5.8 \\
\hline Constant & 37 & 1.1 & 209 & 6.0 & 92 & 2.7 \\
\hline Slight increase & 416 & 11.9 & 710 & 20.4 & 317 & 9.2 \\
\hline Moderate increase & 1074 & 30.8 & 938 & 26.9 & 817 & 23.8 \\
\hline Strong increase & 1875 & 53.8 & 1111 & 31.9 & 1833 & 53.3 \\
\hline
\end{tabular}

As expected, Vallone Calabrese acted similar to Montegrosso-Pallareta because the two sites are geographically very close and, therefore, are in similar microstational and territorial structure conditions. The vegetation decline affected just over $10 \%$ of the investigated land, while more than $86 \%$ of the surfaces showed a trend in positive evolution, of which over $53 \%$ were with very sustained growth rates.

\subsection{Maps of Environmental Criticalities}

The maps of environmental criticalities showing statistically significant decreases in the vegetation were elaborated through the $Z$ Mann-Kendall methodology.

First of all, a regression analysis between the Z Mann-Kendall values and the TheilSen slope values [131] was performed in order to verify the validity of the procedure. The analysis was conducted on each site, considering a circular area with a radius of $1 \mathrm{~km}$. Figure 6 shows a significant correlation between the variables under consideration for each site, with a determination index $\left(R^{2}\right)$ always greater than 0.8 , and even greater than 0.9 in the case of Montegrosso-Pallareta. In more detail, the functional model, $R^{2}$, and the Standard Error of Estimate (SEE) of the linear regression between Z Mann-Kendall and Theil-Sen slope values for the three sites of interest are reported in Table 4.

a)

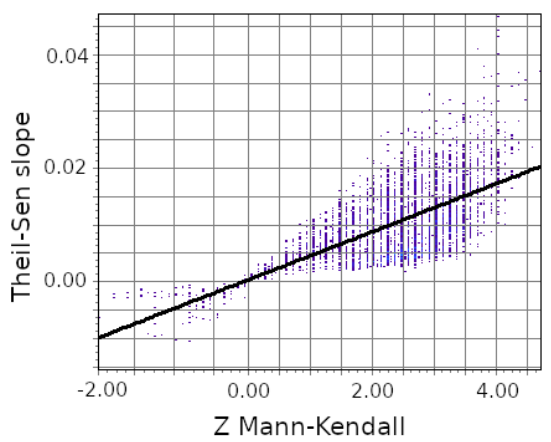

b)

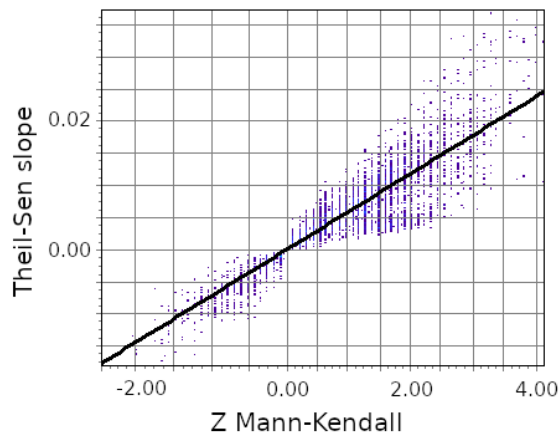

c)

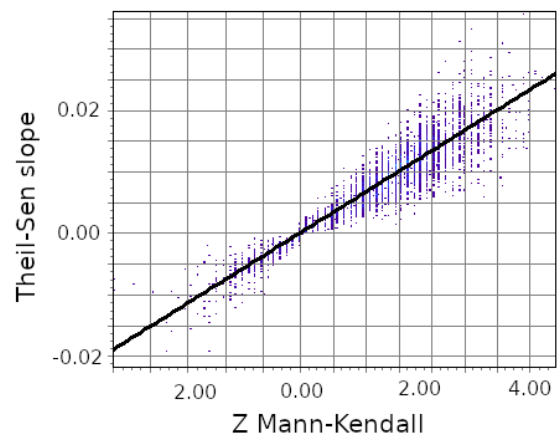

Figure 6. Regression analysis between the Z Mann-Kendall test and Theil-Sen slope values for the three survey sites: (a) Aia dei Monaci, (b) Montegrosso-Pallareta, (c) Vallone Calabrese.

Table 4. Statistical parameters of the regression between $Z$ Mann-Kendall $(X)$ and Theil-Sen slope $(Y)$ for the three sites.

\begin{tabular}{cccc}
\hline & Aia dei Monaci & Montegrosso-Pallareta & Vallone Calabrese \\
\hline Functional Model & $Y=0.000001+0.004313 * X$ & $Y=0.000001+0.005762 * X$ & $Y=0.000001+0.005951 * X$ \\
$\boldsymbol{R}^{\mathbf{2}}$ & 0.82 & 0.87 & 0.94 \\
$S E E$ & 0.00050 & 0.000318 & 0.000268 \\
\hline
\end{tabular}

The detailed maps of environmental criticalities, evaluated through the Z MannKendall test applied on the Theil-Sen median trend of NDVI in the time span considered 
(1990-2018) are depicted for each study area in Figure 7. Further, some sampled points are also represented in these maps, and they are analyzed and discussed below.

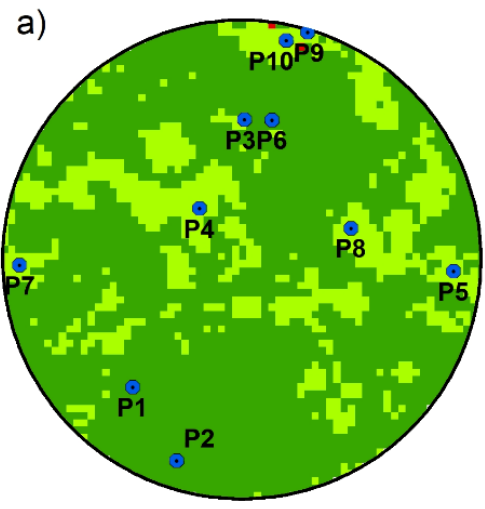

significantly negative

constant
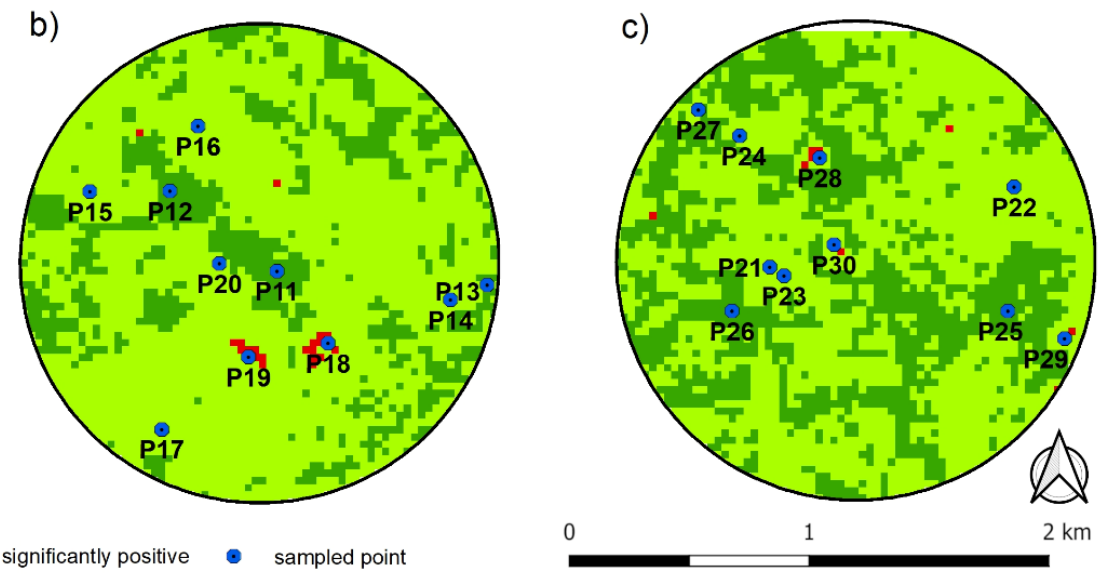

Figure 7. Maps of environmental criticalities and sampled points at the three targeted areas: (a) Aia dei Monaci, (b) Montegrosso-Pallareta, (c) Vallone Calabrese.

Such maps identify the "non-sensitive areas", including portions of land that did not show any significant changes or showed a significant positive trend in the considered period, and "sensitive areas" in which, on the other hand, there was a statistically significant reduction in NDVI. For the three sites, the distribution of the areas of environmental criticality is shown in Table 5.

Table 5. Percentage distribution of the environmental criticality classes for the survey sites.

\begin{tabular}{ccccccc}
\hline \multirow{2}{*}{ Environmental } & \multicolumn{2}{c}{ Aia dei Monaci } & \multicolumn{2}{c}{ Montegrosso-Pallareta } & \multicolumn{2}{c}{ Vallone Calabrese } \\
\cline { 2 - 7 } Criticality Classes & Count & $\mathbf{\%}$ & Count & \% & Count & \% \\
\hline Significantly positive & 2693 & 77.2 & 785 & 22.5 & 1274 & 37.0 \\
Constant & 791 & 22.7 & 2678 & 76.8 & 2159 & 62.7 \\
Significantly negative & 4 & 0.1 & 23 & 0.7 & 12 & 0.3 \\
\hline
\end{tabular}

For Aia dei Monaci, the negative variations, and therefore the areas of environmental criticality, were extremely low, being equal to $0.1 \%$ (only four pixels), while the areas without significant variations were approximately $23 \%$. There were considerable areas (over 77\%) with statistically significant positive variations. Analyzing the map (Figure 7a), it is possible to notice that the areas of environmental criticality were located in the northern part of the circular area of interest and were related to a quarry area already present at the beginning of the time series (1990) that has undergone a progressive expansion over the years.

In the case of the Montegrosso-Pallareta site, the largest surface (approximately 77\%) fell into the "constant" class; unlike Aia dei Monaci, where the largest surfaces in the study area were affected by forest stands, in the site in question, the largest areas were occupied by herbaceous crops (in particular, arable land), which are renewed annually and, therefore, do not show significant variations in terms of quantity of biomass over the years.

For Vallone Calabrese, the percentage distribution of surfaces into criticality classes highlighted a situation that is sufficiently similar to the Montegrosso-Pallareta site as the structure of the landscape is similar in terms of anthropogenic, cultural and natural components. The larger areas (over $60 \%$ ) did not show a significant trend, while the critical areas (significant negative trend) were below $1 \%$. 


\section{Discussion}

In order to identify where the evolutionary trends of vegetation and, therefore, the environmental criticalities have occurred, both maps of the vegetation evolution and related environmental criticalities were intersected with the land use map of the Basilicata region (Figure 2). The intersection of land use with the vegetation evolution classes for each study area is depicted in Figure 8.
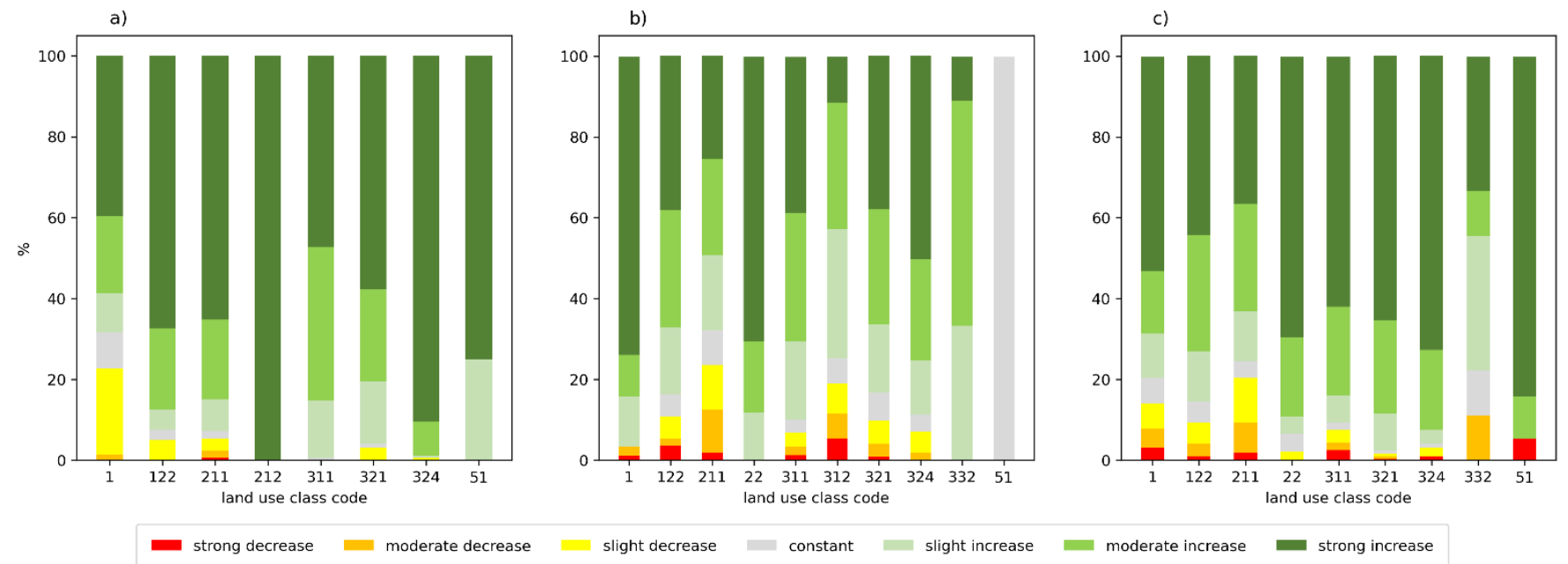

Figure 8. Percentage distribution of vegetation evolution classes vs. land use class code: (a) Aia dei Monaci, (b) Montegrosso-Pallareta, (c) Vallone Calabrese. Land use class codes are described in Table 1.

For Aia dei Monaci (Figure 8a), especially moderate and strong vegetation decreases occurred very often in areas classified as "Non-irrigated arable land" (code 211). The cause was the decrease in NDVI due to a land use change from uncultivated lands (pasture and wooded pasture) to a resumption of cereal cultivation, which has notoriously lower NDVI average values. However, these areas represent only $0.7 \%$ of the entire area of Aia dei Monaci and, as will be seen below, show decreases that the statistical analysis considered insignificant. Further decreases were related to the expansion of urbanized areas, due in particular to the cultivation of a stone quarry located in the north of the study area. The most sustained increases, as expected, concerned areas with forest cover (stands of oak species). The land use class relating to "Transitional woodland-shrub" also showed markedly positive trends. These are areas in which the abandonment of crops or the reduction in livestock pressure has led to the expansion of forest areas. These are the typical areas of forest recolonization.

For Montegrosso-Pallareta (Figure 8b), the vegetation decreases basically affected two land use classes: "Non-irrigated arable land" (code 211) and "Coniferous forest" (code 312). In the first case, the decreases, which are not statistically significant, were due to the resumption of arable farming in previously uncultivated areas (pasture areas) and the crop rotations between cereals and legumes. In the latter, the decrease was sometimes statistically significant.

Instead, forests (both broad-leaved trees and a part of conifer reforestation) and the "transitional woodland/shrub" were characterized by sustained increases. These are areas of forest recolonization, where the abandonment of cultivation has allowed the expansion of shrub and tree vegetation.

For Vallone Calabrese (Figure 8c), the decreases mainly affected arable land, for a similar reason as the Montegrosso-Pallareta site. The NDVI reduction in the "Broad-leaved forest" class (code 311), which was not statistically significant, is due to the management of some areas where this class is present. In particular, the riparian vegetation is subjected to thinning in order to maintain the efficiency of ditches and drains. The increases obviously 
affected the tree vegetation and also the recolonization stage and the "Natural grasslands" (code 321), i.e., the grazing areas where the reduction in anthropogenic pressure (crop abandonment, reduction in grazing pressure) has led to the increase in herbaceous biomass over the years. The intersection between land use classes and maps of environmental criticalities (Figure 9) allows identifying clearly whether vegetation perturbations have occurred over the years due to potentially polluting anthropic activities.
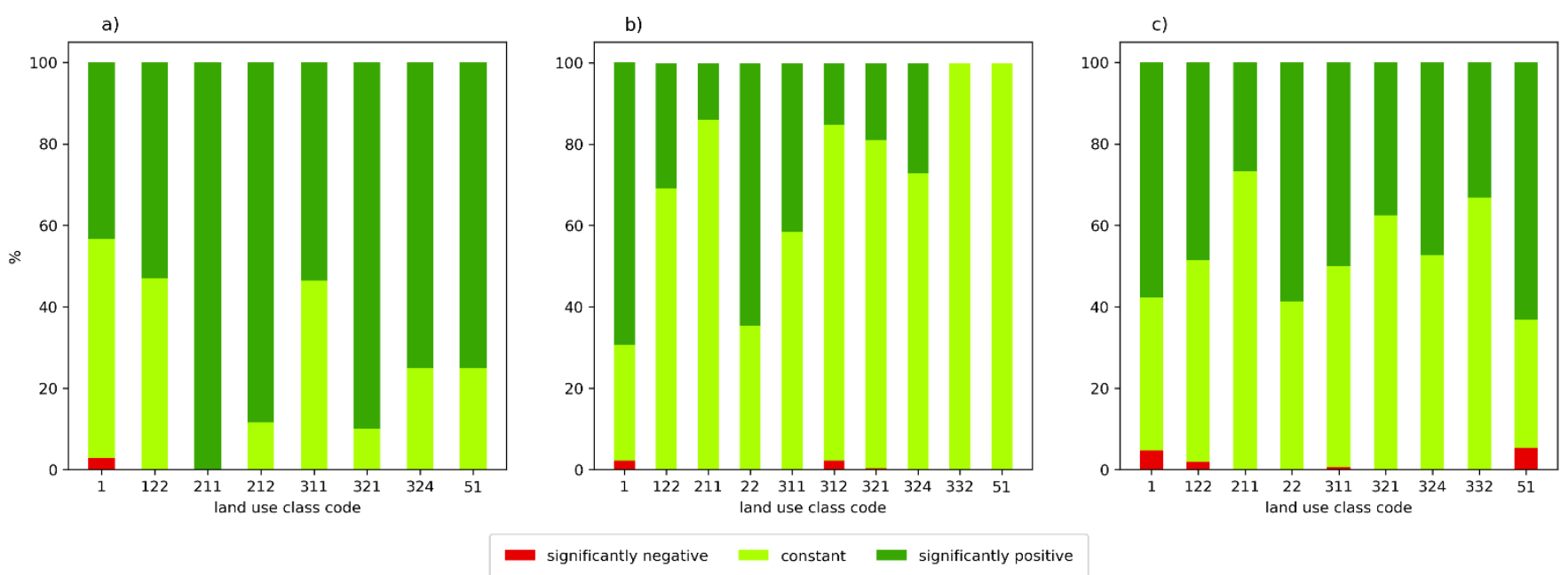

Figure 9. Percentage distribution of environmental criticality classes vs. land use class code: (a) Aia dei Monaci, (b) Montegrosso-Pallareta, (c) Vallone Calabrese. Land use class codes are described in Table 1.

For Aia dei Monaci (Figure 9a), a statistically significant decrease occur in "Artificial surfaces", that is, as already discussed above, the areas located in the north of the site that are characterized by the expansion of a quarry cultivation. The positive changes (significantly increasing trend) are instead related to forest stands, in particular to broadleaved forests (in detail, oak trees) and to areas of forest recolonization ("Transitional woodland-shrub"). The invariant areas fundamentally belong to the "Non-irrigated arable land" class, where there is an annual cycle of cultivation on the same surfaces.

For the Montegrosso-Pallareta site (Figure 9b), the positive trends occur mainly in correspondence with natural surfaces: from forest stands (both broad-leaved and part of the reforested areas with conifers) to the areas of forest recolonization following the reduction in anthropogenic pressure (crop abandonment) and natural herbaceous vegetation areas (pastures). The invariant areas involve both the surfaces with crops (non-irrigated arable land) and the small areas without any vegetation cover. Some conifers' reforestations show an arrest in growth, which had already begun to decline since 1995. A more careful examination of these reforestations allows identifying that the constant decline in terms of biomass is not related to the possible effect due to waste disposal activity, but to the partial failure of these stands due to local conditions, in particular pedological characteristics, and to the inadequate choice of plant species. This is, in fact, a common situation in the reforestation of Basilicata, where the choice of alien species that are not very suitable for extreme climate and above all soil features has led to the constant deterioration of reforested areas over the years, up to the partial or total failure of the plantation.

In the Vallone Calabrese site (Figure 9c), the invariant areas, similarly to the MontegrossoPallareta site, consist of arable land and pasture areas, while the positive trends basically occur both in forest areas and forest recolonization areas. Instead, the critical areas, statistically significant negative trends, are the "Artificial surfaces".

The analysis of NDVI Theil-Sen multitemporal trends of some points of interest (Figures 6 and 10) clarifies the vegetation dynamics in each investigated area. 

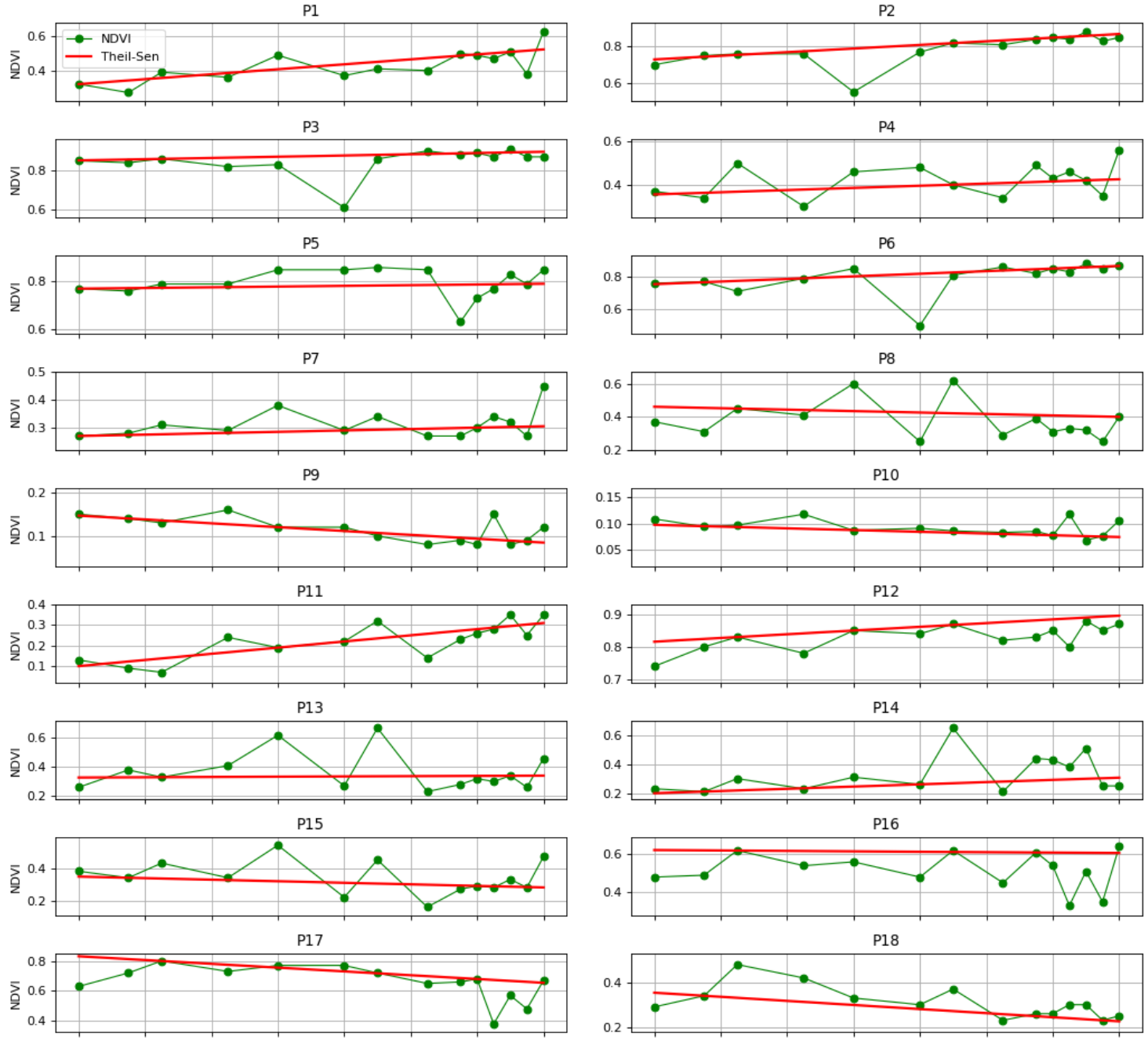

P19
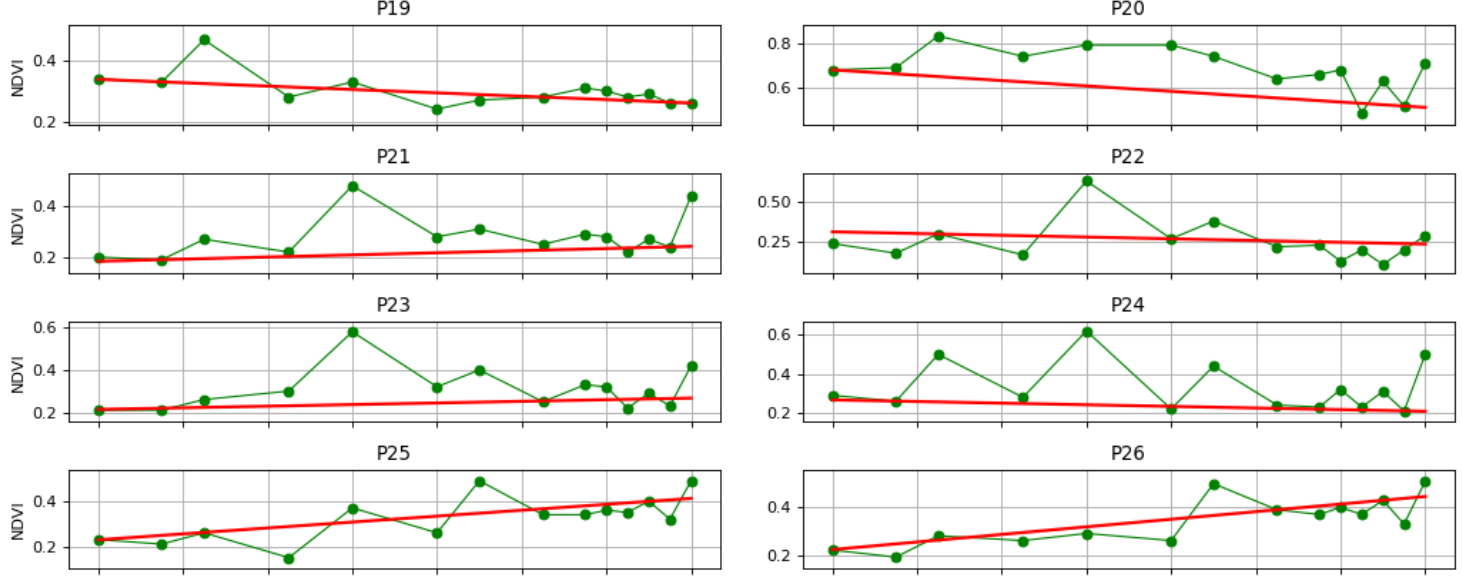

P27

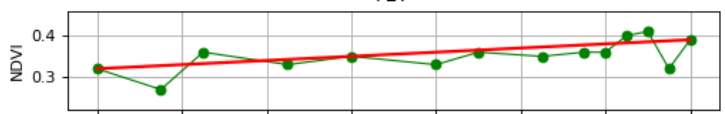

P28
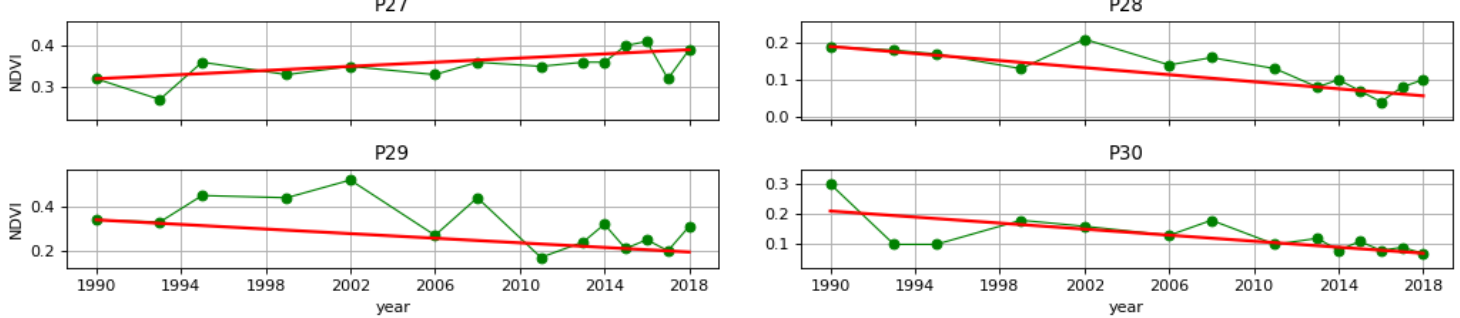

Figure 10. Theil-Sen median trend of sampled points (from P1 to P10 Aia dei Monaci; from P11 to P20 Montegrosso-Pallareta; from P21 to P30 Vallone Calabrese). 
In Aia dei Monaci, the points P9 and P10 fall into critical areas and show decreasing trends. The initial NDVI values in 1990 are already very low (about 0.1 ) and typical of rocky areas with sparse herbaceous vegetation. These values tend to constantly decrease due to the expansion of quarry cultivation over the years. No other areas of environmental criticality can be identified on this site. Then, there are areas (P5) characterized by a constant trend over the years and points that, although showing a slightly increasing (P4 and P7) or decreasing trend (P8), do not appear to have a statistical significance with regard to the $Z$ Mann-Kendall test. As mentioned above, most areas have a statistically significant positive variation in the NDVI (P2 and P6) and are attributable to forest stands.

In Montegrosso-Pallareta, the positive trends are related to forests (P12) also in the recolonization stage (P14) or areas, such as the landfill body itself (P11), characterized by the presence of herbaceous and shrub artificial species, as a result of restoration operations (capping and greening). Points between P18 and P20 correspond to the reforestation stands affected by a forest fire in 2015, as evidenced by a significant decrease in NDVI. However, the growth decline started in 1995 because these plants, as already clarified above, are located in very difficult local conditions, characterized by heavily clayey asphyxiated soils on very high slopes.

For Vallone Calabrese, the invariant points (P22 and P24) consist of arable land and pasture areas, while the positive trends are mainly related to forests, forest recolonization areas (P26 and P25) and pastures (P21) where the reduction in anthropogenic pressure (grazing) has led to a biomass increase. The critical areas (significantly negative trends) are attributable to urbanization and infrastructural works (P28) and, partially, to arable land as a consequence of the restarting of the cultivation of pasture or wooded pastures on small surfaces with consequent biomass reduction (P29).

In summary, the analysis carried out on the three sites in order to identify the presence of the effects on the vegetation of any pollution leads to the conclusion that a significant alteration of plant systems' functionality with a consequent decline in the vegetation were not found in the areas of interest during the period under examination. The significant vegetation decline observable in limited areas of each site was due to landscapes dynamics and the consequent land use changes, or external disturbances with respect to the phenomenon under investigation.

The proposed methodology, which involves the application of the Theil-Sen slope and $Z$ Mann-Kendall test to verify the statistical significance of trends, has proven to be particularly suitable in the processing of collected satellite data and taking into account the perturbations induced on vegetation by different drivers than those to be analyzed. In fact, over a long period of time and with few observations, NDVI variations may be due to external causes (disturbances) able to significantly affect its trends. For instance, a forest fire occurring near Montegrosso-Pallareta in 2015 (Figure 11a) or forest exploitation at Aia dei Monaci (Figure 11b), due to the usual forest management, represent outliers with respect to vegetation trends. In such cases, the Theil-Sen median trend is not affected, unlike OLS regression, by these extreme events, which represent aberrant values compared to the targeted phenomenon. 

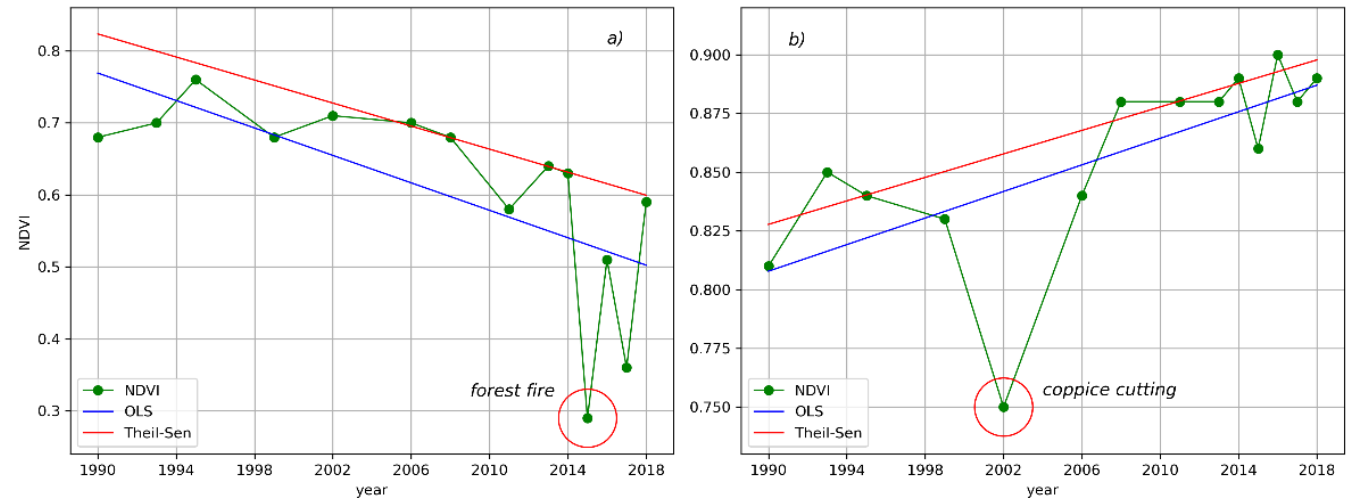

Figure 11. Comparison between the slope trends of NDVI time series (1990-2018) calculated with OLS (blue line) and Theil-Sen estimators (red line) of two sampled points near: (a) Montegrosso-Pallareta, (b) Aia dei Monaci.

\section{Conclusions}

The aim of this work was to verify the possibility of analyzing the effects induced on plant systems in areas surrounding sites where potentially polluting activities take place or have been carried out. The analyses concerned sites located in southern Italy (Basilicata region) intended for the disposal of municipal solid waste and where PTE concentrations above the threshold values permitted by current national legislation were recorded at some stage of their management.

The proposed analyses identified the multitemporal NDVI trends and their significance factually and efficiently, thus allowing the elaboration of maps of the vegetation evolution and related environmental criticalities. The methodology made it possible to evaluate the vegetation evolution per unit area from 1990 to 2018. Ultimately, the adopted workflow was able to discover the presence or absence over time of stressors related to anthropogenic waste disposal activities that could have influenced the significant alteration of plant systems' functionality. The applied methodology was able to exclude negative effects on the vegetation due to potentially polluting activities. In fact, the environmental criticalities were not very spatially large near the three sites of interest. In more detail, in Aia dei Monaci, the critical areas were almost absent, representing about $0.1 \%$ (0.36 ha) of the entire study area (ab. $314 \mathrm{ha}$ ), while in Montegrosso-Pallareta and Vallone Calabrese, the areas with a significant decrease in vegetation were $0.7 \%$ (2.0 ha) and $0.3 \%$ (1.0 ha), respectively. As widely discussed, such critical areas can be traced back to external factors (disturbances) rather than to pollution due to waste disposal activities.

In conclusion, it should be emphasized that the methodological approach adopted in this work has a general validity; it is not site-specific, thus it is exportable in other territorial contexts. It can be suitably applied to other activities with a high impact on the environment (e.g., mining, oil extraction, exploitation of groundwater, etc.) or natural phenomena that may induce eco-physiological stress on vegetation, affecting its functional efficiency and dynamics. Namely, the impacts that can be induced on ecological systems by global change in relation to phenology or productivity, such as forest fires and subsequent vegetation recovery, the risk of desertification, urbanization processes and all kinds of man-made pollution that can affect ecosystem functionalities.

Author Contributions: Conceptualization, G.M. and A.F.; methodology, G.M.; software, G.M. and A.F.; validation, G.M.; formal analysis, G.M. and M.G.; investigation, G.M.; resources, M.L.T.; data curation, G.M. and A.F.; writing-original draft preparation, G.M. and A.F.; writing-review and editing, G.M., A.F. and R.C.; visualization, M.G., C.I. and M.L.T.; supervision, G.M.; project administration and funding acquisition, M.L.T. and R.C. All authors have read and agreed to the published version of the manuscript. 
Funding: The APC was funded by Centro di Geomorfologia Integrata per l'Area del Mediterraneo (CGIAM).

Institutional Review Board Statement: Not applicable.

Informed Consent Statement: Not applicable.

Data Availability Statement: The data presented in this study are openly available here: http: / / www.webgis-simbiosi.it/, accessed on 13 November 2021.

Acknowledgments: The present work was a further result of the project "SIMBioSi" (2017-2019), co-financed by the Basilicata region. We sincerely thank Antonio Chiriaco for his work on data collection.

Conflicts of Interest: The authors declare no conflict of interest.

\section{References}

1. Blank, L.W. A New Type of Forest Decline in Germany. Nature 1985, 314, 311-314. [CrossRef]

2. Panagos, P.; Van Liedekerke, M.; Yigini, Y.; Montanarella, L. Contaminated Sites in Europe: Review of the Current Situation Based on Data Collected through a European Network. J. Environ. Public Health 2013, 2013, e158764. [CrossRef] [PubMed]

3. Lausch, A.; Erasmi, S.; King, D.J.; Magdon, P.; Heurich, M. Understanding Forest Health with Remote Sensing-Part II-A Review of Approaches and Data Models. Remote Sens. 2017, 9, 129. [CrossRef]

4. $\quad$ Lausch, A.; Borg, E.; Bumberger, J.; Dietrich, P.; Heurich, M.; Huth, A.; Jung, A.; Klenke, R.; Knapp, S.; Mollenhauer, H.; et al. Understanding Forest Health with Remote Sensing, Part III: Requirements for a Scalable Multi-Source Forest Health Monitoring Network Based on Data Science Approaches. Remote Sens. 2018, 10, 1120. [CrossRef]

5. Förstner, U.; Wittmann, G.T.W. Metal Pollution in the Aquatic Environment, 2nd ed.; Springer Study Edition; Springer: Berlin/Heidelberg, Germany, 1981; ISBN 978-3-540-12856-4.

6. Järup, L. Hazards of Heavy Metal Contamination. Br. Med. Bull. 2003, 68, 167-182. [CrossRef]

7. Singh, J.; Kalamdhad, A. Effects of Heavy Metals on Soil, Plants, Human Health and Aquatic Life. Int. J. Res. Chem. Environ. 2011, $1,15-21$.

8. Santos, E.S.; Abreu, M.M.; Batista, M.J.; Magalhães, M.C.F.; Fernandes, E. Inter-Population Variation on the Accumulation and Translocation of Potentially Harmful Chemical Elements in Cistus ladanifer L. from Brancanes, Caveira, Chança, Lousal, Neves Corvo and São Domingos Mines in the Portuguese Iberian Pyrite Belt. J. Soils Sediments 2014, 14, 758-772. [CrossRef]

9. Nabulo, G.; Black, C.R.; Young, S.D. Trace Metal Uptake by Tropical Vegetables Grown on Soil Amended with Urban Sewage Sludge. Environ. Pollut. 2011, 159, 368-376. [CrossRef]

10. Bai, J.; Xiao, R.; Cui, B.; Zhang, K.; Wang, Q.; Liu, X.; Gao, H.; Huang, L. Assessment of Heavy Metal Pollution in Wetland Soils from the Young and Old Reclaimed Regions in the Pearl River Estuary, South China. Environ. Pollut. 2011, 159, 817-824. [CrossRef]

11. Foucault, Y.; Lévêque, T.; Xiong, T.; Schreck, E.; Austruy, A.; Shahid, M.; Dumat, C. Green Manure Plants for Remediation of Soils Polluted by Metals and Metalloids: Ecotoxicity and Human Bioavailability Assessment. Chemosphere 2013, 93, 1430-1435. [CrossRef]

12. Iavazzo, P.; Adamo, P.; Boni, M.; Hillier, S.; Zampella, M. Mineralogy and Chemical Forms of Lead and Zinc in Abandoned Mine Wastes and Soils: An Example from Morocco. J. Geochem. Explor. 2012, 113, 56-67. [CrossRef]

13. Agnieszka, B.; Tomasz, C.; Jerzy, W. Chemical Properties and Toxicity of Soils Contaminated by Mining Activity. Ecotoxicology 2014, 23, 1234-1244. [CrossRef] [PubMed]

14. Odumo, B.O.; Carbonell, G.; Angeyo, H.K.; Patel, J.P.; Torrijos, M.; Rodríguez Martín, J.A. Impact of Gold Mining Associated with Mercury Contamination in Soil, Biota Sediments and Tailings in Kenya. Environ. Sci. Pollut. Res. 2014, 21, 12426-12435. [CrossRef] [PubMed]

15. Lv, J.; Liu, Y.; Zhang, Z.; Zhou, R.; Zhu, Y. Distinguishing Anthropogenic and Natural Sources of Trace Elements in Soils Undergoing Recent 10-Year Rapid Urbanization: A Case of Donggang, Eastern China. Environ. Sci. Pollut. Res. 2015, 22, 10539-10550. [CrossRef] [PubMed]

16. Rodríguez Martín, J.A.; Nanos, N. Soil as an Archive of Coal-Fired Power Plant Mercury Deposition. J. Hazard. Mater. 2016, 308, 131-138. [CrossRef] [PubMed]

17. Karbassi, A.R.; Tajziehchi, S.; Afshar, S. An Investigation on Heavy Metals in Soils around Oil Field Area. Glob. J. Environ. Sci. Manag. 2015, 1, 275-282. [CrossRef]

18. Guerrero, L.A.; Maas, G.; Hogland, W. Solid Waste Management Challenges for Cities in Developing Countries. Waste Manag. 2013, 33, 220-232. [CrossRef]

19. Belabed, S.; Lotmani, B.; Abderrahmane, R. Assessment of Metal Pollution in Soil and in Vegetation near the Wild Garbage Dumps at Mostaganem Region. J. Mater. Environ. Sci. 2014, 5, 1551-1556.

20. Igbinomwanhia, D.I.; Ideho, B.A. A Study of the Constraint to Formulation and Implementation of Waste Management Policies in Benin Metropolis, Nigeria. J. Appl. Sci. Environ. Manag. 2014, 18, 197-202. [CrossRef] 
21. Argyraki, A.; Kelepertzis, E. Urban Soil Geochemistry in Athens, Greece: The Importance of Local Geology in Controlling the Distribution of Potentially Harmful Trace Elements. Sci. Total Environ. 2014, 482-483, 366-377. [CrossRef]

22. Jiménez-Ballesta, R.; García-Navarro, F.J.; Bravo, S.; Amorós, J.A.; Pérez-de-los-Reyes, C.; Mejías, M. Environmental Assessment of Potential Toxic Trace Element Contents in the Inundated Floodplain Area of Tablas de Daimiel Wetland (Spain). Environ. Geochem. Health 2017, 39, 1159-1177. [CrossRef] [PubMed]

23. Gupta, N.; Yadav, K.K.; Kumar, V. A Review on Current Status of Municipal Solid Waste Management in India. J. Environ. Sci. 2015, 37, 206-217. [CrossRef]

24. Steffan, J.J.; Brevik, E.C.; Burgess, L.C.; Cerdà, A. The Effect of Soil on Human Health: An Overview. Eur. J. Soil Sci. 2018, 69, 159-171. [CrossRef]

25. Ghosh, M.; Singh, S. A Review on Phytoremediation of Heavy Metals and Utilization of Its By-Products. Appl. Ecol. Environ. Res. 2005, 3. [CrossRef]

26. Demirevska-Kepova, K.; Simova-Stoilova, L.; Stoyanova, Z.; Hölzer, R.; Feller, U. Biochemical Changes in Barley Plants after Excessive Supply of Copper and Manganese. Environ. Exp. Bot. 2004, 52, 253-266. [CrossRef]

27. Park, J.H.; Lamb, D.; Paneerselvam, P.; Choppala, G.; Bolan, N.; Chung, J.-W. Role of Organic Amendments on Enhanced Bioremediation of Heavy Metal(Loid) Contaminated Soils. J. Hazard. Mater. 2011, 185, 549-574. [CrossRef]

28. Ivanov, Y.V.; Kartashov, A.V.; Ivanova, A.I.; Savochkin, Y.V.; Kuznetsov, V.V. Effects of Zinc on Scots Pine (Pinus sylvestris L.) Seedlings Grown in Hydroculture. Plant Physiol. Biochem. 2016, 102, 1-9. [CrossRef]

29. Mathur, S.; Kalaji, H.M.; Jajoo, A. Investigation of Deleterious Effects of Chromium Phytotoxicity and Photosynthesis in Wheat Plant. Photosynthetica 2016, 54, 185-192. [CrossRef]

30. Zaanouni, N.; Gharssallaoui, M.; Eloussaief, M.; Gabsi, S. Heavy Metals Transfer in the Olive Tree and Assessment of Food Contamination Risk. Environ. Sci. Pollut. Res. 2018, 25, 18320-18331. [CrossRef]

31. Sandalio, L.M.; Dalurzo, H.C.; Gómez, M.; Romero-Puertas, M.C.; del Río, L.A. Cadmium-induced Changes in the Growth and Oxidative Metabolism of Pea Plants. J. Exp. Bot. 2001, 52, 2115-2126. [CrossRef] [PubMed]

32. Ortega-Villasante, C.; Rellán-Álvarez, R.; Del Campo, F.F.; Carpena-Ruiz, R.O.; Hernández, L.E. Cellular Damage Induced by Cadmium and Mercury in Medicago Sativa. J. Exp. Bot. 2005, 56, 2239-2251. [CrossRef]

33. Chen, J.; Shiyab, S.; Han, F.X.; Monts, D.L.; Waggoner, C.A.; Yang, Z.; Su, Y. Bioaccumulation and Physiological Effects of Mercury in Pteris Vittata and Nephrolepis Exaltata. Ecotoxicology 2008, 18, 110. [CrossRef]

34. Vuletić, M.; Šukalović, V.H.-T.; Marković, K.; Kravić, N.; Vučinić, Ž.; Maksimović, V. Differential Response of Antioxidative Systems of Maize (Zea mays L.) Roots Cell Walls to Osmotic and Heavy Metal Stress. Plant Biol. 2014, 16, 88-96. [CrossRef] [PubMed]

35. Mera, R.; Torres, E.; Abalde, J. Influence of Sulphate on the Reduction of Cadmium Toxicity in the Microalga Chlamydomonas Moewusii. Ecotoxicol. Environ. Saf. 2016, 128, 236-245. [CrossRef] [PubMed]

36. Singh, V.; Tripathi, B.N.; Sharma, V. Interaction of Mg with Heavy Metals $(\mathrm{Cu}, \mathrm{Cd})$ in T. Aestivum with Special Reference to Oxidative and Proline Metabolism. J. Plant Res. 2016, 129, 487-497. [CrossRef] [PubMed]

37. Das, S.K.; Patra, J.K.; Thatoi, H. Antioxidative Response to Abiotic and Biotic Stresses in Mangrove Plants: A Review. Int. Rev. Hydrobiol. 2016, 101, 3-19. [CrossRef]

38. Blasco, B.; Graham, N.S.; Broadley, M.R. R. Antioxidant Response and Carboxylate Metabolism in Brassica Rapa Exposed to Different External Zn, Ca, and Mg Supply. J. Plant Physiol. 2015, 176, 16-24. [CrossRef]

39. Zouari, M.; Ben Ahmed, C.; Elloumi, N.; Bellassoued, K.; Delmail, D.; Labrousse, P.; Ben Abdallah, F.; Ben Rouina, B. Impact of Proline Application on Cadmium Accumulation, Mineral Nutrition and Enzymatic Antioxidant Defense System of Olea europaea L. Cv Chemlali Exposed to Cadmium Stress. Ecotoxicol. Environ. Saf. 2016, 128, 195-205. [CrossRef]

40. Zouari, M.; Ahmed, C.B.; Zorrig, W.; Elloumi, N.; Rabhi, M.; Delmail, D.; Ben Rouina, B.; Labrousse, P.; Ben Abdallah, F. Exogenous Proline Mediates Alleviation of Cadmium Stress by Promoting Photosynthetic Activity, Water Status and Antioxidative Enzymes Activities of Young Date Palm (Phoenix dactylifera L.). Ecotoxicol. Environ. Saf. 2016, 128, 100-108. [CrossRef]

41. Wani, P.A.; Khan, M.S.; Zaidi, A. Effects of Heavy Metal Toxicity on Growth, Symbiosis, Seed Yield and Metal Uptake in Pea Grown in Metal Amended Soil. Bull. Environ. Contam. Toxicol. 2008, 81, 152-158. [CrossRef]

42. Jiang, L.; Bao, A.; Guo, H.; Ndayisaba, F. Vegetation Dynamics and Responses to Climate Change and Human Activities in Central Asia. Sci. Total Environ. 2017, 599-600, 967-980. [CrossRef] [PubMed]

43. Liu, D.; Jiang, W.; Gao, X. Effects of Cadmium on Root Growth, Cell Division and Nucleoli in Root Tip Cells of Garlic. Biol. Plant. 2003, 46, 79-83. [CrossRef]

44. Burzyński, M.; Kłobus, G. Changes of Photosynthetic Parameters in Cucumber Leaves under Cu, Cd, and Pb Stress. Photosynthetica 2004, 42, 505-510. [CrossRef]

45. Milton, N.M.; Mouat, D.A. Remote Sensing of Vegetation Responses to Natural and Cultural Environmental Conditions. Photogramm. Eng. 1989, 7.

46. Ekmekçi, Y.; Tanyolaç, D.; Ayhan, B. Effects of Cadmium on Antioxidant Enzyme and Photosynthetic Activities in Leaves of Two Maize Cultivars. J. Plant Physiol. 2008, 165, 600-611. [CrossRef] [PubMed]

47. Dias, M.C.; Monteiro, C.; Moutinho-Pereira, J.; Correia, C.; Gonçalves, B.; Santos, C. Cadmium Toxicity Affects Photosynthesis and Plant Growth at Different Levels. Acta Physiol. Plant. 2013, 35, 1281-1289. [CrossRef] 
48. Barceló, J.; Poschenrieder, C. Plant Water Relations as Affected by Heavy Metal Stress: A Review. J. Plant Nutr. 1990, 13, 1-37. [CrossRef]

49. Farooqui, A.; Kulshreshtha, K.; Srivastava, K.; Singh, S.N.; Farooqui, S.A.; Pandey, V.; Ahmad, P.J. Photosynthesis, Stomatal Response and Metal Accumulation in Cineraria maritima L. and Centauria moschata L. Grown in Metal-Rich Soil. Sci. Total Environ. 1995, 164, 203-207. [CrossRef]

50. Liu, M.; Liu, X.; Zhang, B.; Ding, C. Regional Heavy Metal Pollution in Crops by Integrating Physiological Function Variability with Spatio-Temporal Stability Using Multi-Temporal Thermal Remote Sensing. Int. J. Appl. Earth Obs. Geoinf. 2016, 51, 91-102. [CrossRef]

51. Jin, M.; Liu, X.; Wu, L.; Liu, M. Distinguishing Heavy-Metal Stress Levels in Rice Using Synthetic Spectral Index Responses to Physiological Function Variations. IEEE J. Sel. Top. Appl. Earth Obs. Remote Sens. 2017, 10, 75-86. [CrossRef]

52. Kabata-Pendias, A.; Mukherjee, A.B. Trace Elements from Soil to Human; Springer: Berlin/Heidelberg, Germany, 2007; p. 550. ISBN 978-3-540-32713-4.

53. Lausch, A.; Erasmi, S.; King, D.J.; Magdon, P.; Heurich, M. Understanding Forest Health with Remote Sensing -Part I-A Review of Spectral Traits, Processes and Remote-Sensing Characteristics. Remote Sens. 2016, 8, 1029. [CrossRef]

54. Sridhar, B.B.M.; Han, F.X.; Diehl, S.V.; Monts, D.L.; Su, Y. Spectral Reflectance and Leaf Internal Structure Changes of Barley Plants Due to Phytoextraction of Zinc and Cadmium. Int. J. Remote Sens. 2007, 28, 1041-1054. [CrossRef]

55. Evans, B.; Lyons, T.J.; Barber, P.A.; Stone, C.; Hardy, G. Dieback Classification Modelling Using High-Resolution Digital Multispectral Imagery and in Situ Assessments of Crown Condition. Remote Sens. Lett. 2012, 3, 541-550. [CrossRef]

56. Kancheva, R.; Georgiev, G. Spectrally Based Quantification of Plant Heavy Metal-Induced Stress. In Proceedings of the Remote Sensing for Agriculture, Ecosystems, and Hydrology XIV, Edinburgh, UK, 24-26 September 2012; SPIE: Edinburgh, UK, 2012; Volume 8531, pp. 321-329.

57. Kooistra, L.; Salas, E.A.L.; Clevers, J.G.P.W.; Wehrens, R.; Leuven, R.S.E.W.; Nienhuis, P.H.; Buydens, L.M.C. Exploring Field Vegetation Reflectance as an Indicator of Soil Contamination in River Floodplains. Environ. Pollut. 2004, 127, 281-290. [CrossRef]

58. Horler, D.N.H.; Barber, J.; Barringer, A.R. Effects of Heavy Metals on the Absorbance and Reflectance Spectra of Plants. Int. J. Remote Sens. 1980, 1, 121-136. [CrossRef]

59. Jago, R.A.; Cutler, M.E.J.; Curran, P.J. Estimating Canopy Chlorophyll Concentration from Field and Airborne Spectra. Remote Sens. Environ. 1999, 68, 217-224. [CrossRef]

60. Liu, M.; Liu, X.; Li, J.; Li, T. Estimating Regional Heavy Metal Concentrations in Rice by Scaling up a Field-Scale Heavy Metal Assessment Model. Int. J. Appl. Earth Obs. Geoinf. 2012, 19, 12-23. [CrossRef]

61. Huang, Y.; Liu, X.; Shen, Y.; Liu, S.; Sun, F. Advances in Remote Sensing Derived Agricultural Drought Monitoring Indices and Adaptability Evaluation Methods. Trans. Chin. Soc. Agric. Eng. 2015, 31, 186-195.

62. Chi, G.-Y.; Liu, X.-H.; Liu, S.-H.; Yang, Z.-F. Studies of relationships between Cu pollution and spectral characteristics of TritiZnm aestivum L. Guang Pu Xue Yu Guang Pu Fen Xi Guang Pu 2006, 26, 1272-1276.

63. Sanches, I.D.; Souza Filho, C.R.; Kokaly, R.F. Spectroscopic Remote Sensing of Plant Stress at Leaf and Canopy Levels Using the Chlorophyll 680nm Absorption Feature with Continuum Removal. ISPRS J. Photogramm. Remote Sens. 2014, 97, 111-122. [CrossRef]

64. Broge, N.H.; Leblanc, E. Comparing Prediction Power and Stability of Broadband and Hyperspectral Vegetation Indices for Estimation of Green Leaf Area Index and Canopy Chlorophyll Density. Remote Sens. Environ. 2001, 76, 156-172. [CrossRef]

65. Ji, L.; Peters, A.J. Performance Evaluation of Spectral Vegetation Indices Using a Statistical Sensitivity Function. Remote Sens. Environ. 2007, 106, 59-65. [CrossRef]

66. Glenn, E.P.; Huete, A.R.; Nagler, P.L.; Nelson, S.G. Relationship Between Remotely-Sensed Vegetation Indices, Canopy Attributes and Plant Physiological Processes: What Vegetation Indices Can and Cannot Tell Us About the Landscape. Sensors 2008, 8, 2136-2160. [CrossRef]

67. Jiang, N.; Zhu, W.; Zheng, Z.; Chen, G.; Fan, D. A Comparative Analysis between GIMSS NDVIg and NDVI3g for Monitoring Vegetation Activity Change in the Northern Hemisphere during 1982-2008. Remote Sens. 2013, 5, 4031-4044. [CrossRef]

68. Zhang, Z.; Liu, M.; Liu, X.; Zhou, G. A New Vegetation Index Based on Multitemporal Sentinel-2 Images for Discriminating Heavy Metal Stress Levels in Rice. Sensors 2018, 18, 2172. [CrossRef]

69. Ma, B.; Wang, S.; Mupenzi, C.; Li, H.; Ma, J.; Li, Z. Quantitative Contributions of Climate Change and Human Activities to Vegetation Changes in the Upper White Nile River. Remote Sens. 2021, 13, 3648. [CrossRef]

70. Jin, M.; Liu, X.; Zhang, B. Evaluating Heavy-Metal Stress Levels in Rice Using a Theoretical Model of Canopy-Air Temperature and Leaf Area Index Based on Remote Sensing. IEEE J. Sel. Top. Appl. Earth Obs. Remote Sens. 2017, 10, 3232-3242. [CrossRef]

71. Zhou, H.; Zeng, M.; Zhou, X.; Liao, B.-H.; Liu, J.; Lei, M.; Zhong, Q.-Y.; Zeng, H. Assessment of Heavy Metal Contamination and Bioaccumulation in Soybean Plants from Mining and Smelting Areas of Southern Hunan Province, China. Environ. Toxicol. Chem. 2013, 32, 2719-2727. [CrossRef]

72. Jin, M.; Liu, X.; Wu, L.; Liu, M. An Improved Assimilation Method with Stress Factors Incorporated in the WOFOST Model for the Efficient Assessment of Heavy Metal Stress Levels in Rice. Int. J. Appl. Earth Obs. Geoinf. 2015, 41, 118-129. [CrossRef]

73. Mutanga, O.; Kumar, L. Estimating and Mapping Grass Phosphorus Concentration in an African Savanna Using Hyperspectral Image Data. Int. J. Remote Sens. 2007, 28, 4897-4911. [CrossRef] 
74. Choe, E.; van der Meer, F.; van Ruitenbeek, F.; van der Werff, H.; de Smeth, B.; Kim, K.-W. Mapping of Heavy Metal Pollution in Stream Sediments Using Combined Geochemistry, Field Spectroscopy, and Hyperspectral Remote Sensing: A Case Study of the Rodalquilar Mining Area, SE Spain. Remote Sens. Environ. 2008, 112, 3222-3233. [CrossRef]

75. Kopačková, V. Using Multiple Spectral Feature Analysis for Quantitative PH Mapping in a Mining Environment. Int. J. Appl. Earth Obs. Geoinf. 2014, 28, 28-42. [CrossRef]

76. Dunagan, S.C.; Gilmore, M.S.; Varekamp, J.C. Effects of Mercury on Visible/near-Infrared Reflectance Spectra of Mustard Spinach Plants (Brassica Rapa P.). Environ. Pollut. 2007, 148, 301-311. [CrossRef] [PubMed]

77. Liu, Y.; Chen, H.; Wu, G.; Wu, X. Feasibility of Estimating Heavy Metal Concentrations in Phragmites Australis Using LaboratoryBased Hyperspectral Data-A Case Study along Le'an River, China. Int. J. Appl. Earth Obs. Geoinf. 2010, 12, S166-S170. [CrossRef]

78. Liu, M.; Liu, X.; Ding, W.; Wu, L. Monitoring Stress Levels on Rice with Heavy Metal Pollution from Hyperspectral Reflectance Data Using Wavelet-Fractal Analysis. Int. J. Appl. Earth Obs. Geoinf. 2011, 13, 246-255. [CrossRef]

79. Liu, F.; Liu, X.; Zhao, L.; Ding, C.; Jiang, J.; Wu, L. The Dynamic Assessment Model for Monitoring Cadmium Stress Levels in Rice Based on the Assimilation of Remote Sensing and the WOFOST Model. IEEE J. Sel. Top. Appl. Earth Obs. Remote Sens. 2015, 8 , 1330-1338. [CrossRef]

80. Minkina, T.; Mandzhieva, S.; Chapligin, V.; Motuzova, G.; Sushkova, S.; Fedorov, Y.; Kolesnikov, S.; Bauer, T. Accumulation and Distribution of Heavy Metals in Plants within the Technogenesis Zone. Environ. Eng. Manag. J. 2014, 13, 1307-1315. [CrossRef]

81. Ciszewski, D.; Kubsik, U.; Aleksander-Kwaterczak, U. Long-Term Dispersal of Heavy Metals in a Catchment Affected by Historic Lead and Zinc Mining. J. Soils Sediments 2012, 12, 1445-1462. [CrossRef]

82. Zhang, B.; Wu, P.; Zhao, X.; Wang, Y.; Gao, X. Changes in Vegetation Condition in Areas with Different Gradients (1980-2010) on the Loess Plateau, China. Environ. Earth Sci. 2013, 68, 2427-2438. [CrossRef]

83. Zhu, X.; Zhang, S.; Liu, T.; Liu, Y. Impacts of Heat and Drought on Gross Primary Productivity in China. Remote Sens. 2021, 13, 378. [CrossRef]

84. Vermote, E.F.; Tanre, D.; Deuze, J.L.; Herman, M.; Morcette, J.-J. Second Simulation of the Satellite Signal in the Solar Spectrum, 6S: An Overview. IEEE Trans. Geosci. Remote Sens. 1997, 35, 675-686. [CrossRef]

85. Ouaidrari, H.; Vermote, E.F. Operational Atmospheric Correction of Landsat TM Data. Remote Sens. Environ. 1999, 70, 4-15. [CrossRef]

86. Vermote, E.; Tanre, D.; Deuze, J.; Herman, M.; Morcrette, J.-J. Second Simulation of a Satellite Signal in the Solar Spectrum-Vector (6SV); 6S User Guide Version; ASA Goddard Space Flight Center: Greenbelt, MD, USA, 2006; Volume 3, pp. 1-55.

87. Kotchenova, S.Y.; Vermote, E.F.; Matarrese, R.; Frank, J.; Klemm, J. Validation of a Vector Version of the 6S Radiative Transfer Code for Atmospheric Correction of Satellite Data. Part I: Path Radiance. Appl. Opt. 2006, 45, 6762-6774. [CrossRef]

88. Kotchenova, S.Y.; Vermote, E.F. Validation of a Vector Version of the 6 S Radiative Transfer Code for Atmospheric Correction of Satellite Data. Part II. Homogeneous Lambertian and Anisotropic Surfaces. Appl. Opt. 2007, 46, 4455-4464. [CrossRef]

89. Steven, M.D.; Malthus, T.J.; Baret, F.; Xu, H.; Chopping, M.J. Intercalibration of Vegetation Indices from Different Sensor Systems. Remote Sens. Environ. 2003, 88, 412-422. [CrossRef]

90. Kotchenova, S.Y.; Vermote, E.F.; Levy, R.; Lyapustin, A. Radiative Transfer Codes for Atmospheric Correction and Aerosol Retrieval: Intercomparison Study. Appl. Opt. 2008, 47, 2215-2226. [CrossRef] [PubMed]

91. Zhu, Z.; Woodcock, C.E. Object-Based Cloud and Cloud Shadow Detection in Landsat Imagery. Remote Sens. Environ. 2012, 118, 83-94. [CrossRef]

92. Zhu, Z.; Wang, S.; Woodcock, C.E. Improvement and Expansion of the Fmask Algorithm: Cloud, Cloud Shadow, and Snow Detection for Landsats 4-7, 8, and Sentinel 2 Images. Remote Sens. Environ. 2015, 159, 269-277. [CrossRef]

93. Qiu, S.; He, B.; Zhu, Z.; Liao, Z.; Quan, X. Improving Fmask Cloud and Cloud Shadow Detection in Mountainous Area for Landsats 4-8 Images. Remote Sens. Environ. 2017, 199, 107-119. [CrossRef]

94. Qiu, S.; Zhu, Z.; He, B. Fmask 4.0: Improved Cloud and Cloud Shadow Detection in Landsats 4-8 and Sentinel-2 Imagery. Remote Sens. Environ. 2019, 231, 111205. [CrossRef]

95. Theil: A Rank-Invariant Method of Linear and Polynomial. Available online: https://scholar.google.com/scholar_lookup?hl= en\&volume $=53 \&$ publication_year $=1950 \&$ pages $=386-392 \&$ author $=$ H. + Theil\&title $=\% E 2 \% 80 \% 9$ CA + Rank-Invariant + Method + of +Linear+and+Polynomial+Regression+Analysis \%2C \%E2\%80\%9D (accessed on 20 September 2021).

96. Sen, P.K. Estimates of the Regression Coefficient Based on Kendall's Tau. J. Am. Stat. Assoc. 1968, 63, 1379-1389. [CrossRef]

97. Helsel, D.R.; Hirsch, R.M.; Ryberg, K.R.; Archfield, S.A.; Gilroy, E.J. Statistical Methods in Water Resources; Techniques and Methods; U.S. Geological Survey: Reston, VA, USA, 2020; Volume 4-A3, p. 484.

98. Kang, Y.; Guo, E.; Wang, Y.; Bao, Y.; Bao, Y.; Mandula, N. Monitoring Vegetation Change and Its Potential Drivers in Inner Mongolia from 2000 to 2019. Remote Sens. 2021, 13, 3357. [CrossRef]

99. Carslaw, D.C.; Ropkins, K. Openair-An R Package for Air Quality Data Analysis. Environ. Model. Softw. 2012, 27-28, 52-61. [CrossRef]

100. Munir, S. Analysing Temporal Trends in the Ratios of PM2.5/PM10 in the UK. Aerosol Air Qual. Res. 2017, 17, 34-48. [CrossRef]

101. Xu, Z.X.; Takeuchi, K.; Ishidaira, H. Monotonic Trend and Step Changes in Japanese Precipitation. J. Hydrol. 2003, 279, 144-150. [CrossRef] 
102. Jaeger, E.B.; Seneviratne, S.I. Impact of Soil Moisture-Atmosphere Coupling on European Climate Extremes and Trends in a Regional Climate Model. Clim. Dyn. 2011, 36, 1919-1939. [CrossRef]

103. Eastman, J.R.; Sangermano, F.; Machado, E.A.; Rogan, J.; Anyamba, A. Global Trends in Seasonality of Normalized Difference Vegetation Index (NDVI), 1982-2011. Remote Sens. 2013, 5, 4799-4818. [CrossRef]

104. Ben Abbes, A.; Bounouh, O.; Farah, I.R.; de Jong, R.; Martínez, B. Comparative Study of Three Satellite Image Time-Series Decomposition Methods for Vegetation Change Detection. Eur. J. Remote Sens. 2018, 51, 607-615. [CrossRef]

105. Osunmadewa, B.A.; Gebrehiwot, W.Z.; Csaplovics, E.; Adeofun, O.C. Spatio-Temporal Monitoring of Vegetation Phenology in the Dry Sub-Humid Region of Nigeria Using Time Series of AVHRR NDVI and TAMSAT Datasets. Open Geosci. 2018, $10,1-11$. [CrossRef]

106. Eastman, J.R.; Sangermano, F.; Ghimire, B.; Zhu, H.; Chen, H.; Neeti, N.; Cai, Y.; Machado, E.A.; Crema, S.C. Seasonal Trend Analysis of Image Time Series. Int. J. Remote Sens. 2009, 30, 2721-2726. [CrossRef]

107. Kumar, S.; Merwade, V.; Kinter, J.L.; Niyogi, D. Evaluation of Temperature and Precipitation Trends and Long-Term Persistence in CMIP5 Twentieth-Century Climate Simulations. J. Clim. 2013, 26, 4168-4185. [CrossRef]

108. Winslow, L.A.; Read, J.S.; Hansen, G.J.A.; Hanson, P.C. Small Lakes Show Muted Climate Change Signal in Deepwater Temperatures. Geophys. Res. Lett. 2015, 42, 355-361. [CrossRef]

109. Yeh, C.-F.; Wang, J.; Yeh, H.-F.; Lee, C.-H. Spatial and Temporal Streamflow Trends in Northern Taiwan. Water 2015, 7, 634-651. [CrossRef]

110. Yue, S.; Pilon, P.; Cavadias, G. Power of the Mann-Kendall and Spearman's Rho Tests for Detecting Monotonic Trends in Hydrological Series. J. Hydrol. 2002, 259, 254-271. [CrossRef]

111. Kaspersen, P.S.; Fensholt, R.; Huber, S. A Spatiotemporal Analysis of Climatic Drivers for Observed Changes in Sahelian Vegetation Productivity (1982-2007). Int. J. Geophys. 2011, 2011, e715321. [CrossRef]

112. Liu, C.; Huang, H.; Sun, F. A Pixel-Based Vegetation Greenness Trend Analysis over the Russian Tundra with All Available Landsat Data from 1984 to 2018. Remote Sens. 2021, 13, 4933. [CrossRef]

113. Tian, F.; Wang, Y.; Fensholt, R.; Wang, K.; Zhang, L.; Huang, Y. Mapping and Evaluation of NDVI Trends from Synthetic Time Series Obtained by Blending Landsat and MODIS Data around a Coalfield on the Loess Plateau. Remote Sens. 2013, 5, 4255-4279. [CrossRef]

114. Yang, Y.; Wang, S.; Bai, X.; Tan, Q.; Li, Q.; Wu, L.; Tian, S.; Hu, Z.; Li, C.; Deng, Y. Factors Affecting Long-Term Trends in Global NDVI. Forests 2019, 10, 372. [CrossRef]

115. Mann, H.B. Nonparametric Tests Against Trend. Econometrica 1945, 13, 245-259. [CrossRef]

116. Kendall, M.G. Rank Correlation Methods; Hafner Publishing Company: New York, NY, USA, 1962.

117. Kendall, M.G. Rank Correlation Methods; Griffin: London, UK, 1975; ISBN 978-0-85264-199-6.

118. Lara, M.J.; Nitze, I.; Grosse, G.; McGuire, A.D. Tundra Landform and Vegetation Productivity Trend Maps for the Arctic Coastal Plain of Northern Alaska. Sci. Data 2018, 5, 180058. [CrossRef]

119. Lamchin, M.; Lee, W.-K.; Jeon, S.W.; Wang, S.W.; Lim, C.H.; Song, C.; Sung, M. Long-Term Trend of and Correlation between Vegetation Greenness and Climate Variables in Asia Based on Satellite Data. MethodsX 2018, 5, 803-807. [CrossRef]

120. Li, S.; Yang, S.; Liu, X.; Liu, Y.; Shi, M. NDVI-Based Analysis on the Influence of Climate Change and Human Activities on Vegetation Restoration in the Shaanxi-Gansu-Ningxia Region, Central China. Remote Sens. 2015, 7, 11163-11182. [CrossRef]

121. Liu, Y.; Li, Y.; Li, S.; Motesharrei, S. Spatial and Temporal Patterns of Global NDVI Trends: Correlations with Climate and Human Factors. Remote Sens. 2015, 7, 13233-13250. [CrossRef]

122. Hirsch, R.M.; Slack, J.R. A Nonparametric Trend Test for Seasonal Data With Serial Dependence. Water Resour. Res. 1984, 20, 727-732. [CrossRef]

123. Gilbert, R.O. Statistical Methods for Environmental Pollution Monitoring; Pacific Northwest National Lab. (PNNL): Richland, WA, USA, 1987.

124. De Beurs, K.M.; Henebry, G.M. A Statistical Framework for the Analysis of Long Image Time Series. Int. J. Remote Sens. 2005, 26, 1551-1573. [CrossRef]

125. Hu, K.; Zhang, Z.; Fang, H.; Lu, Y.; Gu, Z.; Gao, M. Spatio-Temporal Characteristics and Driving Factors of the Foliage Clumping Index in the Sanjiang Plain from 2001 to 2015. Remote Sens. 2021, 13, 2797. [CrossRef]

126. McGWIRE, K.; FRIEDL, M.; ESTES, J.E. Spatial Structure, Sampling Design and Scale in Remotely-Sensed Imagery of a California Savanna Woodland. Int. J. Remote Sens. 1993, 14, 2137-2164. [CrossRef]

127. Atkinson, P.; Curran, P. Choosing an Appropriate Spatial Resolution for Remote Sensing Investigations. Photogramm. Eng. Remote Sens. 1997, 63, 1345-1351.

128. Huang, Z.; Liu, X.; Jin, M.; Ding, C.; Jiang, J.; Wu, L. Deriving the Characteristic Scale for Effectively Monitoring Heavy Metal Stress in Rice by Assimilation of GF-1 Data with the WOFOST Model. Sensors 2016, 16, 340. [CrossRef]

129. Li, Q.; Guo, J.; Wang, F.; Song, Z. Monitoring the Characteristics of Ecological Cumulative Effect Due to Mining Disturbance Utilizing Remote Sensing. Remote Sens. 2021, 13, 5034. [CrossRef]

130. Bachmair, S.; Tanguy, M.; Hannaford, J.; Stahl, K. How Well Do Meteorological Indicators Represent Agricultural and Forest Drought across Europe? Environ. Res. Lett. 2018, 13, 034042. [CrossRef]

131. Neeti, N.; Eastman, J.R. A Contextual Mann-Kendall Approach for the Assessment of Trend Significance in Image Time Series. Trans. GIS 2011, 15, 599-611. [CrossRef] 